\title{
24. SECONDARY MINERALS OF BASALTS FROM THE NAURU BASIN, DEEP SEA DRILLING PROJECT LEG 61 ${ }^{1}$
}

\author{
V. B. Kurnosov and I. V. Kholodkevich, Far-East Geological Institute of the Far-East Science Center of the \\ U.S.S.R. Academy of Sciences, Vladivostok, U.S.S.R. \\ and \\ A. Ya. Shevchenko, Institute of Oceanology of the U.S.S.R. Academy of Sciences, Moscow, U.S.S.R.
}

\section{INTRODUCTION}

A Cretaceous volcanic complex has been drilled in Nauru Basin to a depth of 550 meters. This complex is composed of sills, pillow-like flows, and hyaloclastic sediments. The thickness of the sills varies from $20 \mathrm{~cm}$ to tens of meters. The upper part of the complex, from 559 to 730 meters, consists of interlayered sills and hyaloclastic sediments. The lower part of the complex from 730 to 1068 meters, contains only sediments between 994 and 998 meters.

Tholeiitic basalts and dolerites similar in chemical composition to mid-ocean-ridge tholeiites are present in the Nauru Basin. Basalts of the Nauru Basin were affected by hydrothermal alteration and low-temperature sea-water-basalt interaction. The following secondary minerals were identified both in vein complexes and in the groundmass of the basalts: saponite, celadoniteglauconite, chlorite, talc, mixed-layer hydromica-montmorillonite, heulandite, phillipsite, okenite, calcite, gyrolite-truscottite, wairakite, apophyllite, actinolite-tremolite, magnetite, pyrite, iron hydroxide, and quartz. Identification of these minerals is based on X-raydiffraction analysis, electron-diffraction analysis, electron-microscopy data, infra-red spectral analysis, microprobe data, wet analysis, and spectral analysis. Secondary minerals were studied in the $<2-\mu \mathrm{m}$ fraction, in natural basaltic samples, and also in samples from veins and filled vesicles.

\section{SECONDARY MINERALS IN BASALT GROUNDMASS}

Saponite is the dominant secondary mineral in the basalt groundmass (Table 1). Chlorite is rare. Saponite replaces interstitial glass and probably olivine in glassy basalts with porphyro-variolitic and hyalopilitic textures. Basalts with diabasic textures seldom contain saponite. In chilled rinds of Samples 462A-44-2, 12-13 $\mathrm{cm}$ and $462 \mathrm{~A}-47-1,95-96 \mathrm{~cm}$ the glass is fresh, and olivine is altered. Plagioclase and pyroxene are not replaced by clay minerals.

Saponite was identified by X-ray-diffraction analysis in all studied samples of basalt. Petrographic investiga-

\footnotetext{
${ }^{1}$ Initial Reports of the Deep Sea Drilling Project, Volume 61.
}

Table 1. Occurrence of secondary minerals from basalt groundmass, Leg 61.

\begin{tabular}{|c|c|c|c|c|c|}
\hline $\begin{array}{c}\text { Sample } \\
\text { (interval in } \mathrm{cm} \text { ) }\end{array}$ & $\begin{array}{l}\text { Sub-bottom } \\
\text { Depth } \\
\text { (m) }\end{array}$ & Saponite & $Z^{d}$ & Hydromica & Chlorite \\
\hline $462-60-1,65-69$ & 559.0 & $\mathrm{x}$ & 0.90 & $x^{c}$ & \\
\hline $60-1,86-89$ & 559.0 & $\mathrm{x}$ & 0.90 & $x^{c}$ & \\
\hline $60-2,135-138^{\mathrm{a}}$ & 561.0 & $\mathrm{x}$ & 1.00 & & \\
\hline $61-1,48-51$ & 568.0 & $\mathrm{x}$ & 0.94 & & \\
\hline $62-2,135-137^{\mathrm{a}}$ & 579.0 & $\mathrm{x}$ & 0.95 & & \\
\hline $63-2,18-22$ & 581.0 & $\mathrm{x}$ & 0.96 & & \\
\hline $64-1,12-14^{a}$ & 585.5 & $\mathrm{x}$ & 0.95 & & \\
\hline $64-4,23-27$ & 590.0 & $\mathrm{x}$ & 0.95 & & \\
\hline $462 \mathrm{~A}-14-2,4-7$ & 564.0 & $x^{b}$ & & $\mathrm{x}$ & \\
\hline $24-1,12-14$ & 606.0 & $x$ & 0.95 & & \\
\hline $28-1,92-94^{a}$ & 630.5 & $\mathrm{x}$ & 1.00 & & \\
\hline $29-2,105-108$ & 638.0 & $\mathrm{x}$ & 1.00 & & $x^{c}$ \\
\hline $32-1,10-14$ & 655.0 & $\mathrm{x}$ & 0.98 & & \\
\hline $44-2,12-13$ & 730.5 & $\mathrm{x}$ & 0.98 & & \\
\hline $44-2,13-16^{\mathrm{a}}$ & 730.5 & $\mathrm{x}$ & 0.94 & & \\
\hline $47-1,95-96$ & 747.0 & $\mathrm{x}$ & 1.00 & & \\
\hline $47-1,96-98$ & 747.0 & $\mathrm{x}$ & 1.00 & & \\
\hline $52-4,33-36^{\mathrm{a}}$ & 792.0 & $\mathrm{x}$ & 0.94 & & \\
\hline $53-1,143-146$ & 793.0 & $\mathrm{x}$ & 0.86 & & \\
\hline $55-2,50-52^{\mathrm{a}}$ & 803.0 & $\mathrm{x}$ & 0.96 & & \\
\hline $57-1,145-147$ & 816.5 & $\mathrm{x}$ & 0.92 & & \\
\hline $61-6,2-4$ & 859.0 & $\mathrm{x}$ & 1.00 & & \\
\hline $62-2,148-150^{\mathrm{a}}$ & 863.0 & $\mathrm{x}$ & 0.97 & & \\
\hline $62-3,17-19^{\mathrm{a}}$ & 863.5 & $\mathrm{x}$ & 0.99 & & \\
\hline $64-3,46-49$ & 872.5 & $\mathrm{x}$ & 0.98 & & $\mathrm{X}^{\mathrm{c}}$ ? \\
\hline $70-1,20-22$ & 919.0 & $\mathrm{x}$ & 0.97 & & $\mathrm{X}^{\mathrm{c}}$ ? \\
\hline $70-3,91-93$ & 922.5 & $\mathrm{x}$ & 0.90 & & \\
\hline $79-5,144-146$ & 992.0 & $\mathrm{x}$ & 1.00 & & \\
\hline $80-2,122-124$ & 996.5 & $\mathrm{x}$ & 1.00 & & \\
\hline $89-2,15-16$ & 1038.0 & $\mathrm{x}$ & & & \\
\hline $90-3,88-90^{\mathrm{a}}$ & 1045.0 & $\mathrm{x}$ & 0.91 & & \\
\hline
\end{tabular}

a Secondary minerals were studied in the fractions $<2 \mu \mathrm{m}, 2-20 \mu \mathrm{m},>20 \mu \mathrm{m}$, and bulk; other samples were studied in bulk only.

b Mixed-layer hydromica-montmorillonite.

c Mineral as trace.

$\mathrm{d}_{Z} \mathrm{Z}=$ ratio of heights of $17-\AA$ peaks of smectite.

tion showed brown smectite replacing glass and a greenbrown variety (bowlingite) replacing olivine.

$\mathrm{X}$-ray-diffraction patterns show the usual positions of reflections for studied smectites. Weak and wide (001) 11.8- to 13.3 - $\AA$ reflections become unusually narrow and symmetrical after solvation of the sample with ethylene glycol (Table $1 ; Z$ coefficient).

A $b$ parameter of 9.23 to $9.25 \AA$ (Table 2) indicates that the smectite is saponite. A $b$ parameter of $9.04 \AA$ probably shows an $\mathrm{Fe}$-montmorillonite admixture. Electron-diffraction reflections suggest that the studied saponites (Mering, 1975) have semi-ordered and disordered packing of layers (Table 2). A $b$ parameter of $9.09 \AA$ re- 
Table 2. The $b$ parameter of clay minerals from basalt groundmass.

\begin{tabular}{cccc}
\hline $\begin{array}{c}\text { Sample } \\
\text { (interval in cm) }\end{array}$ & $\begin{array}{c}\text { Sub-bottom } \\
\text { Depth } \\
(\mathrm{m})\end{array}$ & $b(\AA)$ & $\begin{array}{c}\text { Type of } \\
\text { Stacking of } \\
\text { Smectite } \\
\text { Layers }\end{array}$ \\
\hline $462-60-1,65-69$ & 559.0 & $9.25 ; 9.09$ & II \\
$60-1,86-89$ & 559.0 & $9.25 ; 9.09$ & II \\
$60-2,135-138$ & 561.0 & $9.25 ; 9.09$ & II \\
$60-1,48-51$ & 568.0 & 9.24 & II \\
$62-2,135-137$ & 579.0 & 9.22 & II \\
$63-2,18-22$ & 581.0 & 9.24 & II \\
$64-1,12-14$ & 585.5 & 9.20 & II \\
$64-4,23-27$ & 590.0 & 9.24 & I \\
$462 A-28-1,92-94$ & 630.5 & 9.23 & II \\
$44-2,13-16$ & 730.5 & 9.22 & II \\
$52-4,33-36$ & 792.0 & 9.22 & I \\
$62-2,148-150$ & 863.0 & 9.22 & I \\
$62-3,17-19$ & 863.5 & 9.23 & I \\
$64-3,46-49$ & 872.5 & $9.25 ; 9.04$ & II \\
$70-1,20-22$ & 919.0 & 9.23 & I \\
$90-3,88-90$ & 1042.5 & 9.24 & II \\
\hline
\end{tabular}

Note: $I$ = turbostratic stacking; $I I=$ semi-ordered stacking (Mering, 1975).

flects a mechanical impurity of mica derived from veinlets and small vesicles.

The saponite has the usual form of equant plates of different size and thickness. Saponite from Sample 452A-55-2, 50-52 cm also contains unusual thread-like varieties (Plate 1, Fig. 1). Under the scanning electron microscope, this saponite shows peculiar texture (Plate 3, Fig. 1). Similar saponites were identified in Sample $462 \mathrm{~A}-70-3,91-93 \mathrm{~cm}$. The texture of saponite (bowlingite) replacing olivine is shown in Plate 4, Figure 1.

In Samples 462A-24-1, 12-14 cm; 462A-32-1, 10-14 $\mathrm{cm}$; and $462 \mathrm{~A}-52-4,33-36 \mathrm{~cm}$, a reflection at $8.4 \AA$ suggests actinolite-tremolite. It probably exists as thin veinlets. In Sample 462A-32-1, 10-14 cm, actinolite-tremolite was identified petrographically in a vein (Table 3 ). In Hole 462A, Sample 14-2, 4-7 cm, a mixed-layer hydromica-montmorillonite mineral and celadonite-glauconite are found near the contact in basalt groundmass.

Chemical analysis of the $<2-\mu \mathrm{m}$ fraction from saponite-rich basalt shows an $\mathrm{Fe}-\mathrm{Mg}$-saponite low in $\mathrm{K}$, (Table 4). Increased $\mathrm{K}$ in Sample 462-60-2, 135-138 cm is due to contamination of the $<2-\mu \mathrm{m}$ fraction by vein celadonite-glauconite (Tables 1 and 2). Average contents of $\mathrm{Al}_{2} \mathrm{O}_{3}, \mathrm{MnO}, \mathrm{CaO}$, and $\mathrm{Na}_{2} \mathrm{O}$ in the $<2-\mu \mathrm{m}$ fraction is greater in basalts from 730 to 1068 meters than in basalts from 559 to 730 meters.

Chemical composition, X-ray-diffraction, infra-red, and electron-diffraction characteristics of the $<2-\mu \mathrm{m}$ fraction from marginal (glassy) and central (well-crystallized) parts of sills show that they have no marked differences except $\mathrm{Mg}$ content, which is higher in saponites from marginal parts. A comparison of these characteristics for saponites from basalts occurring near the top of the basement and far from the contact shows that they are similar, except in total iron. Total iron increases in the $<2-\mu \mathrm{m}$ fraction toward the sediment/ basalt contact. This increase may however be caused by a general iron increase in the upper basaltic complex in the interval from 559 to 730 meters (Shcheka, this volume).

A comparison of chemical analyses of basalts and $<2-\mu \mathrm{m}$ fractions from these basalts shows that the $<2-\mu \mathrm{m}$ fraction contains less $\mathrm{SiO}_{2}, \mathrm{TiO}_{2}$, and $\mathrm{MnO}$, but more total iron and $\mathrm{K}$ than the bulk rock. These peculiarities are most prominent in the upper basaltic complex, from 559 to 730 meters. $\mathrm{Al}_{2} \mathrm{O}_{3}$ content is higher in the $<2-\mu \mathrm{m}$ fraction than in whole-rock basalt compositions of the upper basaltic complex, and lower in basalts of the lower complex. $\mathrm{MgO}$ content shows an inverse relationship to $\mathrm{Al}_{2} \mathrm{O}_{3}$.

Chemical variations of the $<2-\mu \mathrm{m}$ fraction cannot be attributed completely to saponite, because this fraction also contains plagioclase and volcanic glass. Trace element content of the $<2-\mu \mathrm{m}$ fraction is given in Table 5 .

\section{SECONDARY MINERALS IN VEINS AND VESICLES}

The following minerals occur in veins and vesicles of basalts: saponite, celadonite-glauconite, chlorite, talc, mixed-layer hydromica-montmorillonite, heulandite, phillipsite, okenite, calcite, gyrolite-truscottite, wairakite, apophyllite, magnetite, pyrite, iron hydroxide, actinolite-tremolite, and quartz (Table 3 ). These minerals occur in the following types of associations:

1) Saponite with talc;

2) Actinolite-tremolite veins;

3) Saponite with magnetite;

4) Saponite (chlorophaeite);

5) Saponite with Ca-minerals (okenite, calcite, gyrolite-truscottite, heulandite, wairakite, and apophyllite);

6) Saponite with pyrite.

7) Celadonite-glauconite with swelling minerals and iron hydroxides.

\section{Mineralogy}

\section{Saponite}

Saponite occurs in the majority of these assemblages. Vein saponite is black, sometimes brownish; it is darkgreen in association with talc. Microscopic capillary saponite (chlorophaeite) is grass-green. X-ray data on these saponites and their behavior after saturation with ethylene glycol and annealing at $550^{\circ} \mathrm{C}$ for 1 hour are the same as for saponites from the basalt groundmass. However, vein saponite is better crystallized than that in the groundmass; it exhibits a very strong (001) reflection and a series of basal reflections of more-long-range order. Electron-diffraction patterns also show a good resolution of reflections and identify these saponites as semi-ordered (Plate 7, Fig. 1). The $b$ parameter is 9.24 to $9.27 \AA$ (Table 6).

Saponites of the first and the fifth associations have been analyzed most completely. Chemical analyses of the saponites showed $\mathrm{Al}_{2} \mathrm{O}_{3}$ and the $\Sigma \mathrm{FeO}+\mathrm{MgO}$ / $\mathrm{Al}_{2} \mathrm{O}_{3}$ ratio to be greater in vein types than in the $<2-\mu \mathrm{m}$ fraction from the basalt groundmass (Table 7; 
Table 3. Summary of identified secondary minerals in veins and vesicles from basalt, Leg 61 .

\begin{tabular}{|c|c|c|c|c|c|c|c|c|c|c|c|c|c|c|c|c|c|c|c|c|}
\hline $\begin{array}{c}\text { Sample } \\
\text { (interval in cm) }\end{array}$ & $\begin{array}{l}\text { Sub-bottom } \\
\text { Depth } \\
\text { (m) }\end{array}$ & Saponite & $z$ & $\begin{array}{l}\text { Celadonite- } \\
\text { Glauconite }\end{array}$ & Chlorite & Talc & $\begin{array}{l}\text { Mixed-layer } \\
\text { Hydromica- } \\
\text { Montmoril- } \\
\text { Ilonite }\end{array}$ & $\begin{array}{c}\text { Hueland- } \\
\text { ite }\end{array}$ & $\begin{array}{l}\text { Phil- } \\
\text { lipsite }\end{array}$ & Okenite & Calcite & $\begin{array}{c}\text { Gyrolite- } \\
\text { Trusc- } \\
\text { ottite }\end{array}$ & $\begin{array}{c}\text { Waira- } \\
\text { kite }\end{array}$ & $\begin{array}{c}\text { Apo- } \\
\text { phyllite }\end{array}$ & $\begin{array}{l}\text { Mag- } \\
\text { netite }\end{array}$ & Pyrite & $\begin{array}{c}\text { Iron } \\
\text { Hydroxide }\end{array}$ & $\begin{array}{l}\text { Actinolite- } \\
\text { Tremolite }\end{array}$ & Quartz & $\begin{array}{c}\text { Types of } \\
\text { Minerali- } \\
\text { zation }\end{array}$ \\
\hline $462-60-1,65-69$ & 559.0 & $\mathrm{X} ?$ & & $\mathrm{x}$ & & & $x$ & $\mathrm{x}$ & & & $\mathrm{x}$ & & & & & & & & & 7 \\
\hline $60-1,86-89$ & 559.0 & & 0.70 & $x$ & & & $\mathrm{x}$ & & & & & & & & & & $\mathrm{x}$ & & & $\begin{array}{l}7 \\
7\end{array}$ \\
\hline $60-2,135-138$ & 561.0 & $x$ & 0.98 & $\mathrm{x}$ & & & $\mathrm{x}$ & & & & $\mathrm{x}$ & & & & & $\mathrm{x}$ & & & & $\begin{array}{l}7 \\
6\end{array}$ \\
\hline $\begin{array}{c}64-4,23-27 \\
462 \mathrm{~A}-14-2,4-7\end{array}$ & $\begin{array}{l}590.0 \\
564.0\end{array}$ & $\mathrm{x}$ & 0.95 & $\mathrm{x}$ & & & $x$ & & & & & & & & & & & & & 7 \\
\hline $\begin{array}{r}462 \mathrm{~A}-14-2,4-7 \\
14-2,4-7\end{array}$ & $\begin{array}{l}564.0 \\
564.0\end{array}$ & & & $\mathrm{x}$ & & & $\hat{x}$ & & & & & & & & & & & $\mathrm{x}$ & & 2 \\
\hline $28-1,92-94$ & 630.5 & $x$ & 0.95 & & & & & & & & & & & & & & & & & $\begin{array}{l}6 \\
3\end{array}$ \\
\hline $30-6,115$ & 653.0 & $x$ & 1.00 & & & & & & & & & & & & $\mathrm{x}$ & & & & & 3 \\
\hline $32-1,10-14$ & 655.5 & $\mathrm{x}$ & 0.98 & & $\mathrm{x}$ & $\mathrm{x}$ & & $\mathrm{x}$ & & & & & & & & & & $\mathrm{x}$ & & ${ }_{5}^{2}$ \\
\hline $41-2,10-11$ & $\begin{array}{l}712.5 \\
732.5\end{array}$ & & & & & & & $\begin{array}{l}x \\
x\end{array}$ & & $\mathrm{x}$ & & & & & & & & & & $\begin{array}{l}S c \\
S d\end{array}$ \\
\hline $45-1,50$ & $\begin{array}{l}733.5 \\
748.5\end{array}$ & $\begin{array}{l}x \\
x\end{array}$ & 0.90 & & & $\mathrm{x}$ & & $\hat{x}$ & & $x$ & & & & & & & & & & $5 \mathrm{~b}$ \\
\hline $\begin{array}{l}47-2,10-11 \\
48-4,101-102\end{array}$ & $\begin{array}{l}748.5 \\
762.5\end{array}$ & $x$ & & & & $\lambda$ & & $\lambda$ & & $\lambda^{2}$ & & & & $\mathrm{x}$ & & & & & & sf \\
\hline $52-4,33-36$ & 792.0 & $\mathrm{x}$ & 0.98 & & & & & & & & $\mathrm{x}$ & & & & & & & & & 6 \\
\hline $54-2,62-64$ & 799.5 & $\mathrm{x}$ & 0.98 & & & & & $\mathrm{x}$ & & $\mathrm{x}$ & $\mathrm{x}$ & $\mathrm{x}$ & & & & & & & & $5 \mathrm{~b}, \mathrm{Se}$ \\
\hline $55-1,110$ & 802.0 & $x$ & 0.95 & & & & & $\mathrm{x}$ & & & & & & & & & & & & 5d \\
\hline $55-2,50-52$ & 803.0 & $\mathrm{x}$ & 0.90 & & & & & & & & & & & & & $\mathrm{x}$ & & & & \\
\hline $56-2,95-97$ & 808.5 & $x$ & 1.00 & & & & & $\mathrm{x}$ & & $\mathrm{x}$ & $\mathrm{x}$ & $\mathrm{x}$ & & & & & & & & $5,5 \mathrm{e}$ \\
\hline $57-1,145-147$ & 816.5 & $x$ & 0.95 & & & & & & & & & & & & & & & & & 6 \\
\hline $58-1,110$ & 825.5 & $\mathrm{x}$ & 0.95 & & & & & $\mathrm{x}$ & & $\mathrm{x}$ & & & & & & & & & & sc \\
\hline $58-3,46-49$ & 827.5 & $\mathrm{x}$ & 0.98 & & $\mathrm{x}$ & & & $\mathrm{x}$ & & & & & $\mathrm{x}$ & & & & & & & sd \\
\hline $60-3,3-5$ & 845.5 & $\mathrm{x}$ & 0.94 & & & & & $\mathrm{x}$ & $\mathrm{x}$ & $x$ & $x$ & $\mathrm{x}$ & & & & & & & & sc \\
\hline $61-1,80$ & 852.0 & $\mathrm{x}$ & & & & & & & & $\mathrm{x}$ & $x$ & & & $\mathrm{x}$ & & & & & & $5 \mathrm{f}$ \\
\hline $61-6,2-4$ & 859.0 & $\mathrm{x}$ & 1.00 & & & & & $\mathrm{x}$ & & $\mathrm{x}$ & $\mathrm{x}$ & $\mathrm{x}$ & & & & & & & & $5 \mathrm{~b}$ \\
\hline $62-2,148-150$ & 863.0 & $\mathrm{x}$ & 1.00 & & & & & & & & & & & & & & & & & 6 \\
\hline $62-3,17-19$ & 863.5 & $\mathrm{x}$ & 0.98 & & & & & & & & & & & & & & & & & 4 \\
\hline $62-3,48-49$ & 863.5 & $\mathrm{x}$ & 1.00 & & & & & $\mathrm{x}$ & & & & & & & & & & & & Se \\
\hline $64-3,46-49$ & 872.5 & $x$ & 1.00 & & & $x$ & & $\mathrm{x}$ & & & & & & & & & & & & $5 \mathrm{~d}$ \\
\hline $67-3,40$ & 895.0 & $\mathrm{x}$ & 0.94 & & & $\mathrm{x}$ & & & & & & & & & & & & & & 1 \\
\hline $70-1,2-3$ & 919.0 & $\mathrm{x}$ & & & & & & & & & $\mathrm{x}$ & & & $\mathrm{x}$ & & & & & $\mathrm{x}$ & $5 f$ \\
\hline $70-1,20-22$ & 919.0 & $\hat{x}$ & 0.96 & & & $\mathrm{x}$ ? & & $\mathrm{x}$ & & & $\mathrm{x}$ & & $\mathrm{x}$ & & & & & & & sd \\
\hline $70-3,40-42$ & 922.0 & $\hat{x}$ & & & & & & & & $x$ & $\mathrm{x}$ & $\mathrm{x}$ & & & & & & & & $5 \mathrm{a}$ \\
\hline $70-3,91-93$ & 922.5 & $\mathrm{x}$ & & & & & & & & $\mathrm{x}$ & $\mathrm{x}$ & $\mathrm{x}$ & & & & & & & & Sa \\
\hline $\begin{array}{l}73-3,91-93 \\
80-2,122-124\end{array}$ & 940.5 & $x$ & & & & & & & & & & & & & & $x$ & & & & $\begin{array}{l}6 \\
6\end{array}$ \\
\hline $80-2,122-124$ & 996.5 & $x$ & 1.00 & & & & & & & & & & & & & $\lambda$ & & & & 0 \\
\hline
\end{tabular}


Table 4. Wet chemical analyses (wt. \%) of saponites from the $<2-\mu \mathrm{m}$ fraction, Leg 61 basalts.

\begin{tabular}{ccccccccccccrr}
\hline $\begin{array}{c}\text { Sample } \\
\text { (interval in cm) }\end{array}$ & $\mathrm{SiO}_{2}$ & $\mathrm{TiO}_{2}$ & $\mathrm{Al}_{2} \mathrm{O}_{3}$ & $\mathrm{Fe}_{2} \mathrm{O}_{3}$ & $\mathrm{FeO}$ & $\mathrm{MnO}$ & $\mathrm{MgO}$ & $\mathrm{CaO}$ & $\mathrm{Na}_{2} \mathrm{O}$ & $\mathrm{K}_{2} \mathrm{O}$ & L.o.i. & $\mathrm{H}_{2} \mathrm{O}^{-}$ & Total \\
\hline $462-60-2,135-138$ & 48.25 & 0.77 & 10.48 & 10.91 & 2.94 & 0.09 & 8.09 & 6.27 & 1.11 & 1.55 & 5.06 & 4.35 & 99.87 \\
$62-2,135-137$ & 44.60 & 0.95 & 11.50 & 10.13 & 2.74 & 0.12 & 8.67 & 5.63 & 1.46 & 0.16 & 4.42 & 9.12 & 99.50 \\
$64-1,12-14$ & 41.90 & 1.17 & 8.95 & 13.96 & 2.87 & 0.13 & 10.17 & 3.38 & 0.97 & 0.11 & 5.76 & 10.23 & 99.60 \\
$462 \mathrm{~A}-28-1,92-94$ & 43.85 & 0.45 & 14.08 & 10.98 & 2.60 & 0.10 & 5.37 & 6.08 & 1.94 & 0.21 & 7.31 & 7.21 & 100.18 \\
$44-2,12-16$ & 42.67 & 0.80 & 15.47 & 12.24 & 3.01 & 0.34 & 7.32 & 11.79 & 1.62 & 0.35 & - & - & - \\
$52-4,33-36$ & 49.60 & 0.84 & 14.58 & 10.12 & 3.40 & 0.15 & 6.70 & 8.16 & 2.02 & 0.21 & 1.62 & 3.03 & 100.43 \\
$55-2,50-52$ & 49.40 & 0.74 & 14.30 & 7.04 & 4.76 & 0.26 & 9.30 & 8.48 & 1.91 & 0.26 & 0.90 & 2.21 & 99.56 \\
$62-3,17-19$ & 47.40 & 0.79 & 10.61 & 8.97 & 3.06 & 0.37 & 13.74 & 8.04 & 1.94 & 0.29 & 2.22 & 2.96 & 100.39 \\
$90-3,88-90$ & 46.50 & 0.80 & 15.91 & 10.48 & 3.08 & 0.13 & 5.55 & 8.68 & 2.56 & 0.16 & - & - & - \\
\hline
\end{tabular}

Table 5. Trace elements (ppm) of secondary minerals in the $<2-\mu \mathrm{m}$ fraction of basalt groundmass, Leg 61 .

\begin{tabular}{lcrrrrrrrrr}
\hline $\begin{array}{c}\text { Sample } \\
\text { (interval in cm) }\end{array}$ & $\begin{array}{c}\text { Sub-bottom } \\
\text { Depth } \\
\text { (m) }\end{array}$ & $\mathrm{Cr}$ & $\mathrm{Ni}$ & $\mathrm{V}$ & $\mathrm{Co}$ & $\mathrm{Zr}$ & $\mathrm{Sc}$ & $\mathrm{Pb}$ & $\mathrm{Sn}$ & $\mathrm{Cu}$ \\
\hline $462-60-2,135-138$ & 561.0 & 60 & 40 & 112 & 13 & 52 & 29 & - & - & 115 \\
$62-2,135-137$ & 579.0 & 27 & 30 & 118 & 12 & 130 & 30 & - & - & 180 \\
Average & & 43 & 35 & 115 & 12 & 91 & 30 & - & - & 148 \\
462A-28-1,92-94 & 630.5 & 4 & 23 & 75 & 11 & 220 & 32 & - & - & 100 \\
$44-2,13-16$ & 730.5 & 110 & 32 & 80 & 6 & 43 & 22 & 20 & 6 & 220 \\
$52-4,33-36$ & 792.0 & 85 & 76 & 105 & 16 & 125 & 20 & 5 & - & 320 \\
$55-2,50-52$ & 803.0 & 130 & 64 & 109 & 9 & 85 & 23 & 7 & - & 230 \\
$62-3,17-19$ & 863.5 & 130 & 55 & 100 & 12 & 120 & 30 & 4 & 5 & 380 \\
Average & & 92 & 50 & 94 & 11 & 118 & 25 & 9 & 5 & 250 \\
\hline
\end{tabular}

Table 6 . The $b$ parameter of clay minerals from veins and vesicles, Leg 61.

\begin{tabular}{cccc}
\hline $\begin{array}{c}\text { Sample } \\
\text { (interval in cm) }\end{array}$ & $\begin{array}{c}\text { Sub-bottom } \\
\text { Depth } \\
(\mathrm{m})\end{array}$ & $b(\AA)$ & $\begin{array}{c}\text { Type of } \\
\text { Stacking of } \\
\text { Smectite } \\
\text { Layers }\end{array}$ \\
\hline $462-60-1,65-69$ & 559.0 & 9.10 & - \\
$60-1,86-89$ & 559.0 & 9.10 & - \\
$60-2,135-138$ & 561.0 & 9.10 & - \\
$462 \mathrm{~A}-14-2,4-7$ & 564.0 & 9.11 & - \\
$54-2,62-64$ & 799.5 & 9.24 & II \\
$56-2,95-97$ & 808.5 & 9.25 & II \\
$60-3,3-5$ & 845.5 & $9.25 ; 9.04$ & II \\
$61-6,2-4$ & 859.0 & 9.27 & II \\
$62-3,48-49$ & 863.5 & 9.25 & II \\
$64-3,46-49$ & 872.5 & 9.25 & II \\
$67-3,40$ & 895.0 & 9.17 & II \\
\hline
\end{tabular}

Note: $\mathrm{I}$ = turbostratic stacking; $\mathrm{II}$ = semi-ordered stacking (Mering, 1975).

Figs. 1 and 2). The $\mathrm{K}$ content of vein saponites is small. The $\mathrm{Na}_{2} \mathrm{O}+\mathrm{K}_{2} \mathrm{O}$ content in vein saponites is the same as in saponite from the basalt groundmass (Fig. 2).

Saponites of assocation 5 are similar in composition to vein saponites from Leg 34 basalts (Seyfried et al., 1978). Saponite of the first association contains $26.14 \%$ $\mathrm{MgO}, 1.64 \% \mathrm{Fe}_{2} \mathrm{O}_{3}, 0.57 \% \mathrm{FeO}, 4.97 \% \mathrm{Al}_{2} \mathrm{O}_{3}$, and $0.08 \% \mathrm{~K}_{2} \mathrm{O}$. Saponites rich in $\mathrm{MgO}$ were found in Leg 37 basalts (Scarfe and Smith, 1977b). The MgO content attributed to saponite is overestimated because of impurities of high-magnesium minerals, e.g., talc in Leg 61 basalts. Electron-diffraction patterns of saponite with talc are shown in Plate 7, Figure 2.

Table 8 gives the results of spectral analysis of vein saponites (types 1 and 5).
Table 7. Chemical composition (wt. \%) of vein saponites in basalt, Leg 61 .

\begin{tabular}{lrcrrcrc}
\hline & 1 & $2^{\mathrm{a}}$ & \multicolumn{1}{c}{3} & \multicolumn{1}{c}{4} & \multicolumn{1}{c}{$5^{\mathrm{a}}$} & \multicolumn{1}{c}{6} & $7^{\mathrm{a}}$ \\
\hline $\mathrm{SiO}_{2}$ & 46.90 & - & 45.60 & 46.40 & - & 46.40 & 42.7 \\
$\mathrm{TiO}_{2}$ & 0.07 & - & 0.58 & 0.10 & - & 0.74 & 0.10 \\
$\mathrm{Al}_{2} \mathrm{O}_{3}$ & 4.97 & 5.5 & 9.95 & 7.96 & 5.3 & 9.14 & 4.5 \\
$\mathrm{Fe}_{2} \mathrm{O}_{3}$ & 1.64 & - & 8.90 & 10.78 & - & 14.97 & - \\
$\mathrm{FeO}$ & 0.57 & $15.0^{\mathrm{b}}$ & 2.52 & 3.81 & $15.1^{\mathrm{b}}$ & 1.49 & $16.2^{\mathrm{b}}$ \\
$\mathrm{MnO}$ & 0.10 & - & 0.10 & 0.08 & - & 0.08 & 0.10 \\
$\mathrm{MgO}$ & 26.14 & 14.0 & 11.09 & 14.62 & 13.3 & 13.98 & 5.6 \\
$\mathrm{CaO}$ & 2.49 & 2.5 & 3.22 & 2.41 & 0.7 & 0.48 & 1.0 \\
$\mathrm{Na}_{2} \mathrm{O}$ & 0.88 & 2.50 & 2.13 & 1.40 & 1.3 & 0.59 & 0.4 \\
$\mathrm{~K}_{2} \mathrm{O}$ & 0.08 & - & 0.40 & 0.11 & - & 0.25 & 4.2 \\
$\mathrm{L.O.i.}$ & 8.60 & - & 8.13 & 7.24 & - & 9.36 & - \\
$\mathrm{H} \mathrm{O}^{-}$ & 7.46 & - & 7.44 & 5.39 & - & 2.59 & - \\
$\mathrm{Total}$ & 99.90 & - & 100.06 & 100.30 & - & 100.27 & - \\
\hline
\end{tabular}

1, saponite with talc (type 1), Sample 462A-67-3, $40 \mathrm{~cm} ; 2-6$, saponite (type 5): 2, Sample 462A-56-2, 95-97 cm; 3, Sample 462A-60-3, 3-5 $\mathrm{cm} ; 4$, Sample 462A-62-3, 48-49 cm; 5 , Sample 462A-64-3, 46-49 $\mathrm{cm}$; 6, Sample 462A-70-1, 20-22 cm; 7, Chlorophaeite (type 4), Sample 462A-73-3, 91-93 cm.

a Microprobe (JXA-5A).

b Total $\mathrm{Fe}$ as $\mathrm{FeO}$.

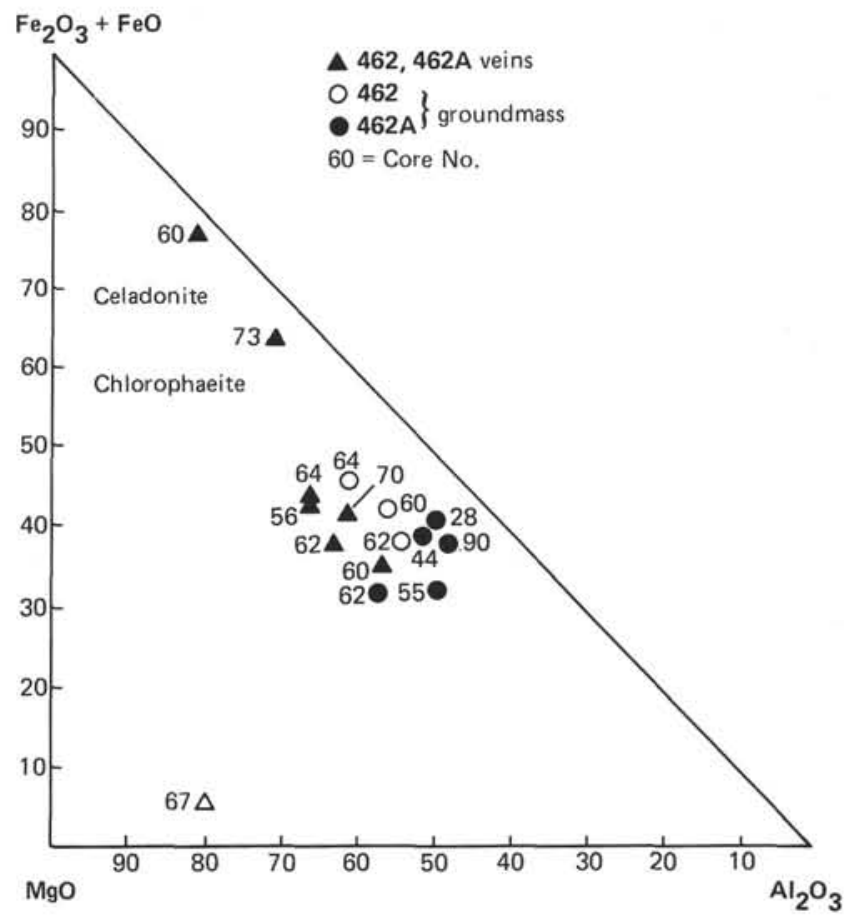

Figure 1. Triangular diagram of $\left(\mathrm{Fe}_{2} \mathrm{O}_{3}+\mathrm{FeO}\right)-\mathrm{Al}_{2} \mathrm{O}_{3}-\mathrm{MgO}$ (wt. \%) for clay minerals from veins and groundmass of basalt at Site 462 . 


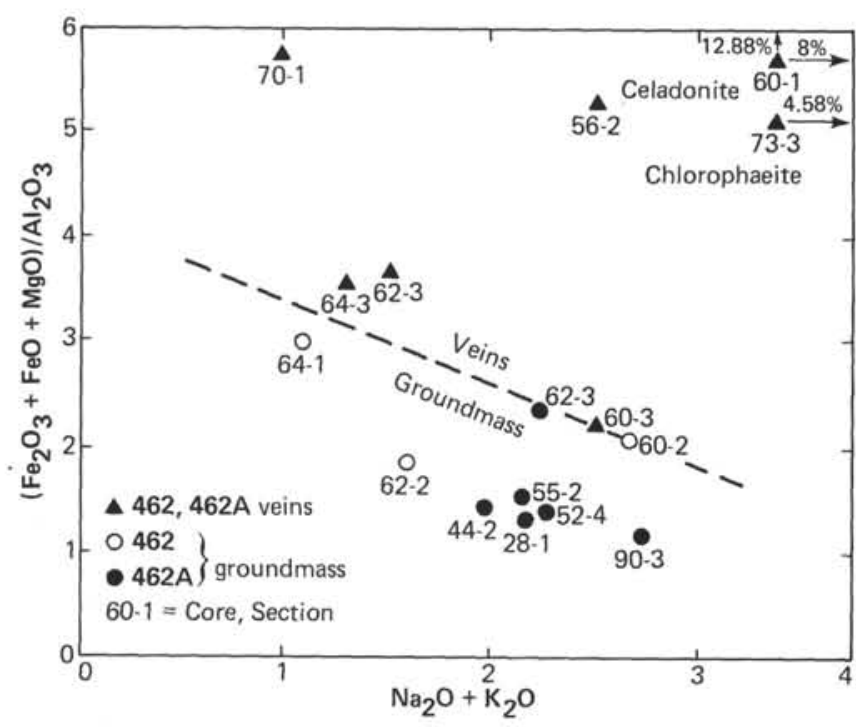

Figure 2. Variation of $\left(\mathrm{Fe}_{2} \mathrm{O}_{3}+\mathrm{FeO}+\mathrm{MgO}\right) / \mathrm{Al}_{2} \mathrm{O}_{3}$ with $\mathrm{Na}_{2} \mathrm{O}+$ $\mathrm{K}_{2} \mathrm{O}$ (wt. \%) in clay minerals from veins and groundmass of basalt at Site 462 .

Table 8. Trace elements (ppm) of clay minerals from veins, Leg 61 .

\begin{tabular}{lcrrrrrrrrr}
\hline $\begin{array}{c}\text { Sample } \\
\text { (interval in cm) }\end{array}$ & $\begin{array}{c}\text { Sub-bottom } \\
\text { Depth } \\
\text { (m) }\end{array}$ & $\mathrm{Cr}$ & $\mathrm{Ni}$ & $\mathrm{V}$ & $\mathrm{Co}$ & $\mathrm{Zr}$ & $\mathrm{Sc}$ & $\mathrm{Pb}$ & $\mathrm{Sn}$ & $\mathrm{Cu}$ \\
\hline $462-60-1,86-89$ & 559.0 & 40 & 75 & 140 & 30 & 47 & 17 & - & - & 35 \\
$462 \mathrm{~A}-30-6,115$ & 653.0 & 32 & 69 & 140 & 24 & 66 & 16 & 5 & 5 & 300 \\
$55-2,50-52$ & 803.0 & 180 & 60 & 120 & - & 21 & 22 & - & - & 150 \\
$57-1,145-147$ & 816.5 & 270 & 160 & 250 & 40 & 42 & 60 & 20 & 5 & 170 \\
$58-3,46-49$ & 827.5 & 10 & 71 & 110 & - & 31 & 4 & - & - & 80 \\
$60-3,3-5$ & 845.5 & 100 & 150 & 270 & 46 & 52 & 25 & - & - & 89 \\
$62-2,148-150$ & 863.0 & 53 & 91 & 100 & 11 & 27 & 14 & - & - & 45 \\
$62-3,48-49$ & 863.5 & 5 & 46 & 68 & 10 & 22 & 3 & - & 5 & 1 \\
$67-3,40$ & 895.0 & 5 & 25 & 14 & - & 32 & 2 & - & - & 1 \\
$70-1,20-22$ & 919.0 & 130 & 57 & 120 & - & 56 & 30 & - & - & 38 \\
Average & & 98 & 91 & 131 & 17 & 43 & 22 & 3 & 2 & 109 \\
\hline
\end{tabular}

Saponite of type 5 occurs mainly as elongated and equant lamellae and loose units (Plate 1, Figs. 2-4). The morphology of saponite and talc (type 2 ) is shown in Plate 2, Figure 1. Scanning electron micrographs reveal diverse saponite morphology (Plate 3, Figs. 2-4; Plate 5, Figs. 1 and 2).

\section{Celadonite-glauconite}

Celadonite-glauconite (Plate 7, Fig. 3) is dioctahedral, of $1 \mathrm{M}$ (3T structure) polytype; $a=5.25 \AA ; b$ $=9.10 \AA ; c=10 \AA ; \beta=101^{\circ}$. In total iron content $(23.6 \%$ total iron as FeO; Table 9), it is similar to glauconite; the $\mathrm{K}_{2} \mathrm{O}$ content is $7.57 \%$. Celadonite of similar chemical composition was identified in Leg 37 basalts (Scarfe and Smith, 1978a). Electron micrographs of celadonite-glauconite show markedly elongated lamellar crystals of irregular density (Plate 2, Fig. 2). Under the scanning electron microscope, one can see its rosette texture (Plate 4, Fig. 2). In a large vesicle of Sample 462A-14-2, 4-7 cm, celadonite-glauconite has a variety of textures (Plate 8). The trace element content of celadonite-glauconite in veins and in veins with saponite is similar (Table 8).
Table 9. Chemical composition (wt. \%) of vein celadoniteglauconite in basalt, Leg 61, (microprobe JXA-5A). Sample $462-60-1,86-89 \mathrm{~cm}$.

\begin{tabular}{lc}
\hline $\mathrm{SiO}_{2}$ & 54.9 \\
$\mathrm{TiO}_{2}$ & 0.06 \\
$\mathrm{Al}_{2} \mathrm{O}_{3}$ & 2.4 \\
$\mathrm{FeO}^{\mathrm{a}}$ & 23.6 \\
$\mathrm{MnO}$ & 0.05 \\
$\mathrm{MgO}$ & 4.9 \\
$\mathrm{CaO}$ & 0.3 \\
$\mathrm{Na}_{2} \mathrm{O}$ & 0.4 \\
$\mathrm{~K}_{2} \mathrm{O}$ & 7.6 \\
\hline
\end{tabular}

a Total $\mathrm{Fe}$ as $\mathrm{FeO}$.

\section{Chlorite and Talc}

Chlorite is barely visible in the X-ray-diffraction pattern of Sample $462 \mathrm{~A}-32-1,10-14 \mathrm{~cm}$. The $9.3 \AA, 4.68$ $\AA$, and $3.12 \AA$ reflections in the X-ray diffraction pattern indicate talc.

\section{Mixed-Layer Minerals}

A mixed-layer hydromica-montmorillonite mineral was identified by X-ray analysis. The X-ray-diffraction pattern of the sample saturated with ethylene glycol shows a (001) reflection equal to $18.6 \AA$, which is asymmetrical, and has a high peak against the background. After heating, the (001) reflection is equal to $9.9 \AA$.

\section{Heulandite}

Heulandite occurs as transparent lamellar and tabular crystals (Plate 5, Fig. 3; Plate 6, Figs. 1 and 2). Heulandite was identified by its strong $8.9 \AA$ reflection and a series of other typical reflections. The chemical composition-especially the $\mathrm{CaO}$ content $(4.0-5.3 \%$; Table 10)-support the identification. The ratio of $\mathrm{X}$-ray reflections also corresponds to standard data on clinoptilolite. Up-section, the $\mathrm{CaO} /$ total alkalies ratio decreases significantly, that is, the heulandite composition changes towards clinoptilolite.

Table 10. Chemical composition (wt. \%) of vein heulandite in basalt, Leg 61 (microprobe JXA-5A).

\begin{tabular}{|c|c|c|c|c|c|}
\hline \multirow[b]{2}{*}{$\begin{array}{c}\text { Component } \\
\text { or Ratio }\end{array}$} & \multicolumn{5}{|c|}{ Sample } \\
\hline & $\begin{array}{l}462 \mathrm{~A}-47-2 \\
10-11 \mathrm{~cm}\end{array}$ & $\begin{array}{c}462 \mathrm{~A}-54-2 \\
62-64 \mathrm{~cm}\end{array}$ & $\begin{array}{l}462 \mathrm{~A}-56-2 \\
95-97 \mathrm{~cm}\end{array}$ & $\begin{array}{c}462 \mathrm{~A}-58-1 \\
110 \mathrm{~cm}\end{array}$ & $\begin{array}{r}462 \mathrm{~A}-64-3 \\
46-49 \mathrm{~cm}\end{array}$ \\
\hline $\mathrm{SiO}_{2}$ & 61.1 & 61.7 & 63.3 & 60.0 & 59.7 \\
\hline $\mathrm{TiO}_{2}$ & - & - & - & - & - \\
\hline $\mathrm{Al}_{2} \mathrm{O}_{3}$ & 14.4 & 14.7 & 17.2 & 15.0 & 16.2 \\
\hline $\mathrm{FeO}^{\mathrm{a}}$ & - & - & - & - & - \\
\hline $\mathrm{MnO}$ & - & - & - & - & - \\
\hline $\mathrm{MgO}$ & - & - & - & - & - \\
\hline $\mathrm{CaO}$ & 4.0 & 4.4 & 4.7 & 4.9 & 5.3 \\
\hline $\mathrm{Na}_{2} \mathrm{O}$ & 1.5 & 1.2 & 0.5 & 1.3 & 1.2 \\
\hline $\mathrm{K}_{2} \mathrm{O}$ & 0.5 & 0.2 & - & 0.3 & 0.4 \\
\hline Total & 81.5 & 82.2 & - & 81.5 & 82.8 \\
\hline$\frac{\mathrm{CaO}}{\mathrm{NaO}}$ & \multirow[t]{2}{*}{2.0} & \multirow[t]{2}{*}{3.1} & \multirow[t]{2}{*}{-} & \multirow[t]{2}{*}{3.0} & \multirow[t]{2}{*}{3.8} \\
\hline $\mathrm{Na}_{2} \mathrm{O}+\mathrm{K}_{2} \mathrm{O}$ & & & & & \\
\hline
\end{tabular}

a Total $\mathrm{Fe}$ as $\mathrm{FeO}$. 


\section{Phillipsite}

Phillipsite was identified by faint 7.1 - and 3.18 - $\AA$ reflections.

\section{Okenite and Ca Minerals}

The okenite is milk-white; it occurs as thick lamellae (Plate 5, Fig. 4) and contains up to $27 \% \mathrm{CaO}$ (Table 11). It was identified by strong $X$-ray reflections at 19.6 and $8.8 \AA$. Calcite was detected by its 3.03 - $\AA$ reflection. A mineral of the gyrolite-truscottite group was identified by only two reflections: 9.6 and $7.4 \AA$. Wairakite was identified by strong reflections at 5.56 and $3.42 \AA$.

\section{Apophyllite}

Apophyllite is green and pink, massive, and pan-like. It contains about $9 \% \mathrm{CaO}$, up to $4.8 \% \mathrm{~K}_{2} \mathrm{O}$ (Table 12), and $0.54 \% \mathrm{~F}$. The complete set of X-ray reflections was detected for apophyllite, the strongest being at 7.7, 4.5, $2.973,2.477$, and $1.583 \AA$.

Table 11. Chemical composition (wt. \%) of vein okenite in basalt, Leg 61.

\begin{tabular}{lccccr}
\hline & \multicolumn{5}{c}{ Sample } \\
\cline { 2 - 6 } Component & $\begin{array}{c}462 \mathrm{~A}-47-2, \\
10-11 \mathrm{~cm}\end{array}$ & $\begin{array}{c}462 \mathrm{~A}-54-2, \\
62-64 \mathrm{~cm}\end{array}$ & $\begin{array}{c}462 \mathrm{~A}-56-2^{\mathrm{a}} \\
95-97 \mathrm{~cm}\end{array}$ & $\begin{array}{c}462 \mathrm{~A}-58-1^{\mathrm{a}} \\
110 \mathrm{~cm}\end{array}$ & $\begin{array}{r}462 \mathrm{~A}-70-3, \\
40-42 \mathrm{~cm}\end{array}$ \\
\hline $\mathrm{SiO}_{2}$ & 54.70 & 54.20 & - & - & 54.90 \\
$\mathrm{TiO}_{2}$ & 0.00 & 0.00 & - & - & 0.00 \\
$\mathrm{Al}_{2} \mathrm{O}_{3}$ & 1.80 & 0.66 & 0.17 & - & 0.56 \\
$\mathrm{Fe}_{2} \mathrm{O}_{3}$ & 0.58 & 0.23 & - & - & 1.04 \\
$\mathrm{FeO}_{\mathrm{MnO}}$ & 0.20 & 0.20 & - & - & 0.20 \\
$\mathrm{MgO}$ & 0.13 & 0.11 & - & - & 0.07 \\
$\mathrm{CaO}$ & 0.00 & 0.00 & - & 0.00 & 0.00 \\
$\mathrm{Na}{ }_{2} \mathrm{O}$ & 24.92 & 27.25 & 27.6 & 25.6 & 26.85 \\
$\mathrm{~K}_{2} \mathrm{O}$ & 1.86 & 1.16 & 1.5 & 0.4 & 1.27 \\
$\mathrm{L.o.i}$ & 0.12 & 0.05 & - & - & 0.09 \\
$\mathrm{H}_{2} \mathrm{O}-$ & 12.9 & 13.81 & - & - & 13.03 \\
Total & 2.61 & 1.86 & - & - & 2.10 \\
\hline
\end{tabular}

${ }^{a}$ Microprobe (JXA-5A).

Table 12. Chemical composition (wt, \%) of vein apophyllite in basalt, Leg 61 .

\begin{tabular}{lcr}
\hline & \multicolumn{2}{c}{ Sample } \\
Component & $\begin{array}{c}462 \mathrm{~A}-60-1, \\
80 \mathrm{~cm}^{\mathrm{a}}\end{array}$ & $\begin{array}{c}462 \mathrm{~A}-70-1, \\
2-3 \mathrm{~cm}\end{array}$ \\
\hline $\mathrm{SiO}_{2}$ & - & 75.60 \\
$\mathrm{TiO}_{2}$ & - & 0.00 \\
$\mathrm{Al}_{2} \mathrm{O}_{3}$ & - & 0.93 \\
$\mathrm{Fe}_{2} \mathrm{O}_{3}$ & - & 2.01 \\
$\mathrm{FeO}$ & - & 0.27 \\
$\mathrm{MnO}$ & - & 0.05 \\
$\mathrm{MgO}$ & - & 1.86 \\
$\mathrm{CaO}$ & - & 9.19 \\
$\mathrm{Na} 2 \mathrm{O}$ & 0.26 & 0.22 \\
$\mathrm{~K}_{2} \mathrm{O}$ & 4.80 & 3.03 \\
$\mathrm{L.0.i.}$ & - & 7.11 \\
$\mathrm{H} 2 \mathrm{O}-$ & - & 0.24 \\
$\mathrm{Total}$ & - & 100.51 \\
\hline
\end{tabular}

${ }^{a}$ Microprobe (JXA-5A).
Fe Minerals, Actinolite-Tremolite, and Quartz

Magnetite, pyrite, and iron hydroxide were identified visually. The chemical composition of iron hydroxide is given in Table 13. Amorphous iron hydroxide contains $1.39 \% \mathrm{~K}$ [X-ray reflections] at $8.4,4.23,4.0,3.32,3.24$, $2.73,2.52$, and $2.13 \AA$ indicate actinolite-tremolite. Quartz was easily identified by its 4.25 - and $3.34-\AA$ reflections.

\section{Associations of Secondary Minerals}

\section{Saponite with Talc}

A Saponite-talc vein occurs in Sample 462A-67-3, 40 $\mathrm{cm}$. Saponite is more abundant than talc. The vein has a deep-green, waxy appearance. In the central part of the vein is a thin light strip, in which occurs the highest quantity of talc. Microprobe analyses do not show different $\mathrm{Mg}, \mathrm{Fe}, \mathrm{Al}, \mathrm{K}$, and $\mathrm{Ni}$ contents in the dark-green marginal part and light central part, although places enriched with $\mathrm{Ca}$ are found in the light part. The saponite-talc vein occurs near the central part of a thick sill.

\section{Veins with Actinolite-Tremolite}

Veins of this type occur in Sample 462A-32-1, 10-14 $\mathrm{cm}$. Black and brownish parts of these veins were investigated. In both cases the secondary minerals are dominantly saponite, with an admixture of actinolitetremolite, chlorite, and talc. Talc is more abundant in the brownish colored variety. The vein lies at the base of thick sill, near the basalt sediment contact. Actinolite-tremolite also occurs in a beige veinlet of Sample 462A-14-2, 4-7 cm, together with celadonite and mixed-layer hydromica-montmorillonite.

\section{Saponite with Magnetite}

A saponite-magnetite vein was studied in Sample $462 \AA-30-6,115 \mathrm{~cm}$. Saponite $(d(060)=1.53 \AA)$ occurs

Table 13. Chemical composition (wt. \%) of vein iron hydroxides in basalt, Leg 61 (microprobe JXA-5A).

\begin{tabular}{|c|c|c|}
\hline & 1 & 2 \\
\hline $\mathrm{SiO}_{2}$ & 10.1 & 4.0 \\
\hline $\mathrm{TiO}_{2}$ & 0.2 & - \\
\hline $\mathrm{Al}_{2} \mathrm{O}_{3}$ & 0.7 & 0.4 \\
\hline $\mathrm{FeO}^{\mathrm{a}}$ & 66.2 & 73.9 \\
\hline $\mathrm{MnO}$ & 0.2 & 0.2 \\
\hline $\mathrm{MgO}$ & 1.0 & 0.4 \\
\hline $\mathrm{CaO}$ & 0.2 & 0.1 \\
\hline $\mathrm{Na}_{2} \mathrm{O}$ & 0.03 & 0.01 \\
\hline $\mathrm{K}_{2} \mathrm{O}$ & 1.4 & 0.01 \\
\hline
\end{tabular}

1 , iron hydroxide, Sample $462-60-1,86-89 \mathrm{~cm} ; 2$, iron hydroxide after pyrite, Sample 462-60-1, $86-89 \mathrm{~cm}$.

a Total $\mathrm{Fe}$ as $\mathrm{FeO}$. 
at the margin of the vein. The vein occurs in the lower part of a thick sill, just above a sedimentary interlayer. A similar vein also lying in a thick sill is described in the shipboard report from 462-69-1.

\section{Saponite (Chlorophaeite)}

Grass-green saponite (chlorophaeite) fills small vesicles in samples 462A-62-3, 17-19 cm and 462A-73-3, $91-93 \mathrm{~cm}$. In its X-ray-diffraction patterns, it resembles saponite from the groundmass (Plate 3, Fig. 4). In a scanning electron micrograph one can see its lace-like, globular texture. Microprobe analysis of Sample 462A73-3, 91-93 cm showed a low $\mathrm{MgO}$ content (5.6\%), and a high $\mathrm{K}_{2} \mathrm{O}$ content $(4.2 \%)$ (Table 7).

\section{Saponite with Ca Minerals}

This type has several sub-types. Veins of the first subtype are composed of okenite. At the junction with enclosing basalt there are thin saponite gouges. The okenite always has impurities of calcite and gyrolitetruscottite. Veins of this composition are present in Samples 462A-70-3, 40-42 cm and 462A-70-3, 91-93 $\mathrm{cm}$.

Veins containing this assemblage of minerals, plus heulandite at the okenite-saponite junction, are attributed to the second sub-type.

The chief mineral of the third sub-type is transparent, tabular heulandite. The heulandite contains rounded growths of snow-white okenite. Okenite was identified in Sample 462A-58-1, $110 \mathrm{~cm}$ by X-ray diffraction and microprobe analysis.

Calcite and gyrolite-truscottite were not identified, probably because of the small amounts of okenite.

The marginal parts of these veins are composed of saponite. In Sample 462A-60-3, 3-5 cm a phillipsite impurity was identified in saponite.

Veins are filled with heulandite and saponite at the basalt/sediment contact are attributed to the fourth sub-type. In Samples 462A-58-3, 46-49 cm and 462A$70-1,20-22 \mathrm{~cm}$, an admixture of wairakite was identified in saponite. A 9.3- $\AA$ reflection, attributed to talc, was also detected in the latter sample.

In the fifth sub-type, saponite makes up the major part of a vein. There are thin heulandite veins in the saponite.

The sixth sub-type differs from the others by the presence of apophyllite in addition to okenite, calcite, heulandite, quartz, and saponite.

Veins of the fifth type are common in thin sills, mainly near or inside glassy rinds. The obtained data and shipboard core descriptions show that veins of this type are widespread from Core $41(712 \mathrm{~m})$ to Core 76 $(960 \mathrm{~m})$. Zeolites were tentatively identified below 960 meters, according to shipboard descriptions; the sixth sub-type (apophyllite) occurs in all cases near thick sills.

\section{Saponite with Pyrite}

In saponite-pyrite veins, saponite $(d(060)=1.54 \AA)$ makes up the marginal parts of veins; pyrite disseminated in the central parts. According to the shipboard report, this type is most common, and is widespread in basalts of Nauru Basin. The wide distribution of pyrite in Mid-Atlantic Ridge basalts was discovered during DSDP Leg 37 (Robinson et al., 1977). Pyrite was not found in samples from veins of this type from Nauru Basin.

\section{Celadonite-Glauconite with Swelling Minerals and Iron Hydroxides}

This type occurs as veins and vesicle fillings only in the upper part of glassy basalts, immediately beneath the sediment boundary, 1 to 2 meters below the contact.

Celadonite-glauconite, iron hydroxides, and impurities of mixed-layer hydromica-montmorillonite and saponite are observed in dark-green veins. A microprobe profile of $\mathrm{Fe}, \mathrm{Mg}$, and $\mathrm{K}$ shows that celadoniteglauconite is surrounded by iron hydroxides with different $\mathrm{Fe}, \mathrm{Mg}$, and $\mathrm{K}$ contents.

Celadonite-glauconite was also identified in Sample $462 \mathrm{~A}-14-2,4-7 \mathrm{~cm}$ in large vesicles with a zonal structure. The outer part is composed of bluish-green matter, containing celadonite-glauconite and small impurities of mixed-layer hydromica-montmorillonite. In the central part of the vesicle, there are needle-shaped and irregular celadonite-glauconite crystals (Plate 8). Celadonite-glauconite and mixed-layer hydromica-montmorillonite were identified in the same sample in basalt groundmass.

\section{DISCUSSION OF RESULTS}

The results show that secondary minerals in the tholeiitic basalts of Nauru Basin originated mainly from solution-basalt interaction at different $E h, p \mathrm{H}$, and $T$. Table 14 shows the conditions of growth of secondary minerals in Leg 61 basalts.

\section{Temperature}

\section{High-Temperature Minerals $\left(350-500^{\circ} \mathrm{C}\right)$}

Talc, chlorite, actinolite-tremolite, and magnetite are the highest-temperature secondary minerals of these basalts. These minerals occur in vein associations of types 1,2, and 3, of thick sills. In experiments modeling hydrothermal alteration of tholeiitic basalt by sea water, the temperature of formation of talc is $500^{\circ} \mathrm{C}$, actinolite-tremolite $400^{\circ} \mathrm{C}$, magnetite $300(?)-400^{\circ} \mathrm{C}$ (Mottl and Holland, 1978).

\section{Middle-Temperature Minerals $\left(100-350^{\circ} \mathrm{C}\right)$}

Minerals of the fifth-type of assocation (heulandite, okenite, calcite, gyrolite-truscottite, wairakite, apophyllite, phillipsite, and quartz) belong to a middletemperature group. Mottle and Holland (1978) experimentally produced wairakite, quartz, truscottite, and pyrite at $300^{\circ} \mathrm{C}$. Senderov and Khitarov (1970) formed wairakite at about $300^{\circ} \mathrm{C}$ temperature and heulanite below $170^{\circ} \mathrm{C}$. They also found that heulandite originated at temperatures up to $230^{\circ} \mathrm{C}$ in Yellowstone National Park. Apohpyllite probably originates at or near $100^{\circ} \mathrm{C}$. 
Table 14. Conditions of formation of secondary minerals in Leg 61 basalt.

\begin{tabular}{|c|c|c|c|c|c|c|c|c|c|c|c|}
\hline \multirow[b]{2}{*}{ Mineral } & \multicolumn{3}{|c|}{ Temperature } & \multirow[b]{2}{*}{ Acidic } & \multirow{2}{*}{$\begin{array}{l}\text { Near } \\
\text { Neutral }\end{array}$} & \multirow[b]{2}{*}{ Alkalic } & \multirow[b]{2}{*}{ Oxidizing } & \multirow{2}{*}{$\begin{array}{c}\text { Non- } \\
\text { oxidizing }\end{array}$} & \multirow[b]{2}{*}{ Groundmass } & \multirow[b]{2}{*}{ Veins } & \multirow[b]{2}{*}{ Vesicles } \\
\hline & High & Middle & Low & & & & & & & & \\
\hline Celadonite & & & $\mathrm{X}$ & & $\mathrm{X}$ & & $\mathrm{X}$ & & & $\mathrm{x}$ & $\mathrm{x}$ \\
\hline Iron hydroxide & & & $\mathrm{x}$ & & $\mathrm{x}$ & & $x$ & & & $\mathrm{X}$ & \\
\hline $\begin{array}{l}\text { Mixed-layer hydromica- } \\
\text { montmorillonite }\end{array}$ & & & $\mathrm{x}$ & & $\mathrm{x}$ & & $\mathrm{x}$ & & & $\mathrm{X}$ & $\mathrm{x}$ \\
\hline Saponite & & & $\mathrm{x}$ & & $\mathrm{x}$ & $\mathrm{x}$ & & $\mathrm{x}$ & $\mathrm{x}$ & $\mathrm{x}$ & \\
\hline Magnetite & $\mathrm{x}$ & & & & $\mathrm{x}$ & & & $\mathrm{x}$ & & $\mathrm{X}$ & \\
\hline Pyrite & & & $\mathrm{X}$ & $\mathrm{X}$ & & & & $\mathrm{X}$ & & $\mathrm{X}$ & \\
\hline Chlorite & $\mathrm{X}$ & & $\mathrm{x}$ & & & $\mathrm{x}$ & & $\mathrm{x}$ & $\mathrm{x}$ & $\mathrm{X}$ & \\
\hline Talc & $\mathrm{X}$ & & & & & $\mathrm{X}$ & & $\mathrm{x}$ & & $\mathrm{X}$ & \\
\hline Actinolite-tremolite & $\mathrm{x}$ & & & & & $\mathrm{x}$ & & $\mathrm{x}$ & & $\mathrm{X}$ & \\
\hline Heulandite & & $\mathrm{X}$ & & & & $\mathrm{x}$ & & $\mathrm{X}$ & & $\mathrm{X}$ & \\
\hline Phillipsite & & $\mathrm{X}$ & & & & $\mathrm{X}$ & & $\mathrm{X}$ & & $\mathrm{X}$ & \\
\hline Wairakite & & $\mathrm{x}$ & & & & $\mathrm{x}$ & & $\mathrm{X}$ & & $\mathrm{x}$ & \\
\hline Okenite & & $\mathrm{X}$ & & & & $\mathrm{X}$ & & $\mathrm{X}$ & & $\mathrm{X}$ & \\
\hline Gyrolite-truscottite & & $\mathrm{X}$ & & & & $\mathrm{X}$ & & $\mathrm{X}$ & & $\mathrm{X}$ & \\
\hline Calcite & & $\mathrm{x}$ & & & & $\mathrm{X}$ & & $\mathrm{X}$ & & $\mathrm{X}$ & \\
\hline Apophyllite & & $\mathrm{X}$ & & & & $\mathrm{X}$ & & $\mathrm{X}$ & & $\mathrm{X}$ & \\
\hline Quartz & & $\mathrm{X}$ & & & & $\mathrm{x}$ & & $\mathrm{x}$ & & $\mathrm{X}$ & \\
\hline
\end{tabular}

\section{Low-Temperature Minerals (below $100^{\circ} \mathrm{C}$ )}

Low-temperature minerals are saponite, celadoniteglauconite, mixed-layer hydromica-montmorillonite, iron hydroxides, and probably pyrite. Oxygen-isotope studies of vein clay minerals and calcite of Nasca Plate basalts (DSDP Leg 34) showed that the temperature of formation of these minerals is about $4^{\circ} \mathrm{C}$ (Seyfried et al., 1976). Later, the temperature was determined to be $\leq 25^{\circ} \mathrm{C}$ (Seyfried et al., 1978). Saponites from different-temperature veins of Nauru Basin basalts probably have had different temperatures of formation-the highest in association with talc and magnetite, middle in veins of type 5 , and lowest in veins with pyrite and iron hydroxides and in basalt groundmass. Hydrothermal alteration of tholeiitic basalt by sea water in closed and semi-closed experimental systems supports the probability of saponite formation at different temperatures in the interval 150 to $700^{\circ} \mathrm{C}$ (Mottl et al., 1978; Kotov et al., 1978). In these experiments, as well as in Nauru Basin basalts, plagioclases and pyroxenes are unaltered. Fresh plagioclases and pyroxenes are also identified in basalts of the Mid-Atlantic Ridge (Leg 37; Robinson et al., 1977; Andrews et al., 1977).

\section{Oxidation Regime}

The occurrence of smectite in nearly all mineral associations suggests that secondary-mineral formation took place under oxidizing conditions. Bass (1976) showed that saponite was formed in a nearly closed system. In such a system, basalt-sea-water interaction occurs, with little water exchange, low fugacity, and high $p \mathrm{H}$ values. Under experimental conditions resembling natural ones, saponite replaced glassy tholeiitic basalt (Kotov et al., 1978). The replacement of interstitial material of basalt groundmass and olivine by smectite in Leg 37 basalts also took place under reducing conditions (Robinson et al., 1977).

Vein minerals originated mainly under reducing conditions. An exception is the upper part of the basalt complex of the Nauru Basin, near the sediment/basalt contact. In this narrow interval of the section, celadonite-glauconite, mixed-layer hydromica-montmorillonite, and iron hydroxides (type 7), originated under oxidizing conditions in veins and vesicles and in basalt groundmass, but only in Hole $462 \mathrm{~A}$. The origin of these minerals in veins of Leg 34 basalts (Bass, 1976; Seyfried et al., 1978) was due to oxidizing conditions. At the contact of basalts and water-saturated sediments the seawater-basalt system was more open than in other parts of the basalt complex of Nauru Basin. Oxidizing conditions were due to rather active water exchange.

Thus, in the sill complex of the Nauru Basin, unlike in pillow lavas of the Mid-Atlantic Ridge (e.g., Leg 37; Robinson et al., 1978) secondary minerals originated mainly under reducing conditions. In the pillow lavas of Leg 37, mineral formation in veins took place under oxidizing conditions, whereas in the basalt groundmass alteration occurred under reducing conditions.

\section{Acidity-Alkalinity Regime}

Secondary minerals in the basalts of Nauru Basin were formed mainly under alkaline conditions. The main indicators of medium alkalinity are heulandite and smectite. It is found experimentally that heulandite grows at increased $p \mathrm{H}$, in alkaline or near-neutral reaction (Senderov and Khitarov, 1970). According to Senderov and Khitarov, saponite originates with a decrease of $p \mathrm{H}$ and cation concentration in the solution. Pyrite and quartz probably originated under acidic conditions. Celadonite-glauconite, mixed-layer hydromica-montmorillonite, and iron hydroxides may have originated in both weakly acidic and near-neutral regimes.

\section{Sources of Material}

$\mathrm{Fe}-\mathrm{Mg}$-saponite in basalt groundmass replaces glass, and partly replaces olivine. The quantities of basaltic glass are enough for the formation of saponite by seawater-glass interaction, a process which has been convincingly demonstrated by experiments showing re- 
placement of glassy tholeiitic basalt by saponite (Kotov et al., 1978). Fischer (1977), who investigated secondary smectites from Mid-Atlantic Ridge basalts, came to the conclusion that they grew without an outside source of material. Seyfried et al. (1978) described the formation of hypothetical smectite as a result of interaction between basaltic glass and water.

Cooling lava and sediments were the main sources of vein minerals. In thick sills, recrystallization of which resulted in the formation of a granitic residue (Shcheka, this volume), conditions were appropriate for the growth of actinolite-tremolite, magnetite, high-magnesium saponite, and talc. In addition, K- and F-bearing minerals were formed, particularly potassium feldspar and fluorapatite (Shcheka, this volume). These minerals reflect the composition of a gas-liquid phase containing $\mathrm{K}$ and $\mathrm{F}$. Degassing of thick sills without glassy rinds probably led to the formation of apophyllite $\left(\mathrm{K}_{2} \mathrm{O}\right.$ content up to $4.8 \%$, $\mathrm{F}$ up to $0.54 \%$ ) in overlying thin basaltic layers with glassy rinds. Quartz, reflecting postmagmatic activity, was identified in the apophyllite (Naboko, 1969) chlorophaeite containing $4.2 \% \mathrm{~K}_{2} \mathrm{O}$ formed under the same conditions.

Heulandite, okenite, calcite, gyrolite-truscottite, and wairakite (association of type 5) from thin sills with glassy rinds are probably the product of pneumatolytic metasomatism. It has been shown experimentally that all components necessary for the growth of zeolites may be leached from volcanic rocks by hot water at increased pressure (Ellis and Mahon, 1964, 1967). Underlying thick sills probably supplied additional material. The occurrence of heulandite, apophyllite, and quartz in Sample 462A-70-1, 2-3 cm supports this suggestion.

High $\mathrm{K}$ and $\mathrm{Fe}^{+3}$ contents in associations of type 7 veins probably reflect the peculiarities of an oxidizing and acidic regime, which provided the conditions for concentration of these elements. These veins occur in the uppermost part of the sill complex of the Nauru Basin. Naboko (1969) showed that in the zone of solution degassing, $\mathrm{SiO}_{2}$ and $\mathrm{K}$ were transported to the rock.

\section{The History of Formation of Secondary Minerals}

Secondary minerals in tholeiitic basalts of the sill complex from Nauru Basin were formed during a postmagmatic stage of hydrothermal condition, and by lowtemperature sea-water-basalt interaction. The vein and mineral parageneses have not yet been studied, because of lack of material.

During the cooling of a portion of the intruded magma, the solution circulating in fractures was composed of volatile components of the magma (mostly water, $\mathrm{CO}_{2}$, and $\mathrm{H}_{2} \mathrm{~S}$; Averyanov et al., 1961) and seawater. This hot solution may have leached enclosing rocks (basalt, sediments) to a great degree. Bishoff and Seyfried (1978) showed that as the temperature increases in a closed system sea water becomes more acid, reaching a $p \mathrm{H}$ as low as 2.52 at $350^{\circ} \mathrm{C}$.

Because of the interaction with cooling basalts and leaching of the latter, the solution changes from markedly acidic to alkaline, causing deposition of vein minerals. In the final stages of mineral formation, the solution became nearly neutral, or acidic. Vein minerals were formed under reducing conditions, except in the thin near-contact zone.

Mineral associations of types $1,2,3$, and 4 were formed during the cooling of thick sills. Talc, chlorite, actinolite-tremolite, and magnetite were formed, followed by saponite. Degassing of thick sills led to the formation of apophyllite and quartz in overlying thin basaltic layers. This process was probably also responsible for formation of the fifth type of association, developed in thin basalt units. In the thin units, this mineral assemblage was formed at medium temperatures. Its formation is related to pneumatolytic metasomatism, which is possible in the presence of screens (glassy rinds). The formation of high-Ca mineralscalcite, okenite, and gyrolite-truscottite, accompanied by heulandite-reflects a high $\mathrm{CO}_{2}$ potential (Senderov and Khitarov, 1970).

A peculiar complex of minerals was formed in the upper part of the basalts: celadonite-glauconite, mixedlayer hydromica-montmorillonite, and iron hydroxides. The growth of these minerals is related to oxidizing conditions during the post-magmatic stage. These conditions were better developed in rocks of Hole $462 \mathrm{~A}$ than in those of Hole 462.

During the final stage of sill cooling, an additional system of fractures appeared. A net of these thin fractures filled with low-temperature saponite and pyrite is developed throughout the sills.

The influence of sediment interlayers in the basement upon the composition of vein minerals is not completely understood. In the shipboard report, Shcheka pointed out the development of calcitic veins near sediments. We had no samples of calcitic veins at our disposal.

Secondary minerals of the basalt groundmass were formed during the final stages of sill cooling, after their complete solidification, mainly by interaction of interstitial water and primary glass. The possibility of seawater penetration into basement to a depth of 600 meters is shown by Leg 37 basalts (Scarfe and Smith, 1977b; Robinson et al., 1977). Alteration of basalts is possible at low temperatures, about $4^{\circ} \mathrm{C}$ (Muehlenbachs, 1976; Seyfried et al., 1976). Regional alteration of basalt by sea water probably took place at a higher temperature.

Scarfe and Smith (1977a) who studied secondary minerals from Leg 37 basalts, also suggested two phases of basalt alteration: one at high temperature, during the solidification of a lava flow, and the other resulting from low-temperature basalt-sea-water interaction.

\section{Chemical Changes}

Analysis of chemical compositions of secondary minerals from both vein minerals and basalt groundmass of Nauru Basin suggests that the most mobile species during the formation of secondary minerals were $\mathrm{Si}, \mathrm{Ca}, \mathrm{Fe}^{+2} ; \mathrm{Mg}, \mathrm{Al}, \mathrm{Na}, \mathrm{K}$, and $\mathrm{Mn}$ were slightly mobile; and Ti was almost immobile. Mottl et al., (1978) showed experimentally, that $\mathrm{SiO}_{2}, \mathrm{Ca}, \mathrm{K}, \mathrm{Ba}, \mathrm{B}$, and $\mathrm{CO}_{2}$ were leached from basalt in a closed system, whereas $\mathrm{Na}$ and $\mathrm{Mg}$ were introduced from water to 
form secondary minerals. Study of natural hydrothermal systems in Iceland confirms this conclusion. We also assume that $\mathrm{Na}$ and $\mathrm{Mg}$ were introduced from sea water during formation of secondary minerals, although we do not consider them very important constituents. The possibility of leaching of $\mathrm{Ca}, \mathrm{Mn}, \mathrm{Fe}, \mathrm{Si}$, and other elements from basalt hot sea water has been shown experimentally (Elderfield et al., 1977).

A study of primary alteration of fresh glass to palagonite in Leg 37 tholeiitic basalts showed increases of $\mathrm{H}_{2} \mathrm{O}, \mathrm{K}_{2} \mathrm{O}$, and total $\mathrm{Fe}$, and decreases of $\mathrm{SiO}_{2}, \mathrm{Al}_{2} \mathrm{O}_{3}$, $\mathrm{CaO}, \mathrm{MgO}$, and $\mathrm{Na}_{2} \mathrm{O}$ in the glass (Scarfe and Smith, 1977b). High $\mathrm{FeO}$ and $\mathrm{MgO}$ mobility during the alteration of basalt of the Mid-Atlantic Ridge was established by Leg 37 (Robinson et al., 1977). Under oxidizing, acidic conditions, the mobility of $\mathrm{Fe}, \mathrm{Mn}, \mathrm{K}$, and $\mathrm{Si}$ probably increases, and that of $\mathrm{Mg}, \mathrm{Ca}, \mathrm{Na}, \mathrm{Al}$, and $\mathrm{Ti}$ decreases.

Comparison of trace-element contents in basalts and secondary clay minerals from the basalt groundmass ( $<2-\mu \mathrm{m}$ fraction), as well as in clay minerals from veins, shows similar trends of trace-element distribution in Holes 462 and 462A (Table 15). The largest $\mathrm{Cr}, \mathrm{Ni}, \mathrm{V}$, and Co contents are found in basalts, the smallest ones in the $<2-\mu \mathrm{m}$ fractions from basalts enriched in clay minerals. The smallest $\mathrm{Zr}$ and $\mathrm{Sn}$ contents are in vein clay minerals. Table 15 also shows the mobility of trace elements during secondary alteration of basalt.

\section{CONCLUSIONS}

Secondary minerals in Cretaceous tholeiitic basalts of a sill complex in the Nauru Basin, chemically similar to tholeiites of mid-oceanic ridges, formed under hydrothermal conditions, by low-temperature sea-water-basalt interaction. Secondary-mineral formation took place mainly under reducing, alkaline conditions, in a nearly closed system, over a wide temperature interval. Oxidizing conditions developed only at the contact of the basalt complex with the overlying sediments, resulting in the appearance of celadonite-glauconite, mixedlayer hydromica-montmorillonite, and iron hydroxides. This mineral complex is rich in $\mathrm{K}$ and $\mathrm{Fe}^{+3}$.

Table 15. Average contents (ppm) of trace elements in basalts, Leg 61 .

\begin{tabular}{|c|c|c|c|c|c|c|}
\hline & $\mathrm{Cr}$ & $\mathrm{Ni}$ & V & Co & $\mathrm{Zr}$ & $\mathrm{Sn}$ \\
\hline \multicolumn{7}{|c|}{ Hole 462} \\
\hline 1 & 105 & 75 & 363 & 49 & 105 & 3 \\
\hline 2 & 40 & 75 & 140 & 30 & 47 & - \\
\hline 3 & 43 & 35 & 115 & 12 & 91 & - \\
\hline \multicolumn{7}{|c|}{ Hole $462 \mathrm{~A}$} \\
\hline 1 & 329 & 122 & 352 & 59 & 79 & 4 \\
\hline 2 & 98 & 91 & 131 & 17 & 43 & 2 \\
\hline 3 & 92 & 50 & 94 & 11 & 118 & 5 \\
\hline
\end{tabular}

1 , Shcheka, this volume.

2 , vein clay minerals.

3 , secondary clay minerals $i<2-\mu \mathrm{m}$ fraction) from groundmass basalt.
Formation of secondary minerals led to a change of chemical composition of the lava. Thus, one needs to correct bulk-rock analyses of basalts to account for secondary alteration. Vein minerals reflect the composition of solutions circulating in fractures. The chemical compositions of vein minerals suggest that the cooling sills became depleted in $\mathrm{Si}, \mathrm{Ca}, \mathrm{Fe}$, and $\mathrm{Mg}$, and to a lesser degree in $\mathrm{Al}, \mathrm{Na}, \mathrm{K}$, and $\mathrm{Mn}$. These elements also may have been transported to a sedimentary layer in the main fractures in which hydrothermal solutions circulated and lava was degassing. Trace elements leached from basalt also may have been transported from basalt into residue along these channelways.

Low-temperature regional alteration of glass and olivine in basalts is primarily an isochemical process.

\section{ACKNOWLEDGMENTS}

We thank Dr. S. A. Shcheka, Dr. A. G. Kossovskaya, Dr. I. O. Murdmaa, and Dr. N. V. Kotov, for critical reading of the manuscript; Dr. I. M. Simanovich and Dr. P. Robinson, for reviewing the manuscript; and N. V. Gruda, N. Ju. Zeitlin, G. A. Yudina, L. I. Kovbas, and N. G. Engovatova, for analytical work and putting the manuscript into shape.

\section{REFERENCES}

Andrews, A. J., Barnett, R. L., MacClement, B. A. E., et al., 1977. Zeolite facies metamorphism, geochemistry, and some aspects of trace element redistribution in altered basalts of DSDP Leg 37. In Aumento, F., Melson, W. G., et al., Init. Repts. DSDP, 37: Washington (U.S. Govt. Printing Office), 795-810.

Averyanov, B. B., Naboko, S. I., and Piip, B. I., 1961. Recent hydrothermal metamorphism in areas of active volcanism. Trans. Acad. Sci. U.S.S.R., 137(2):407-410.

Bass, M. N., 1976. Secondary minerals in oceanic basalt, with reference to Leg 34, Deep Sea Drilling Project. In Yeats, R. S., Hart, S. R., et al., Init. Repts. DSDP, 34: Washington (U.S. Govt. Printing Office), 393-432.

Bischoff, J. L., and Seyfried, W. E., 1978. Hydrothermal chemistry of seawater from $25^{\circ}$ to $350^{\circ} \mathrm{C}$. Am. J. Sci., 278(6):838-860.

Elderfield, H., Gunnlaugsson, E., Wakefield, S. J., et al., 1977. The geochemistry of basalt-seawater interactions: evidence from Deception Island, Antarctica, and Reykjanes, Iceland. Mineral. Mag., 41:217-226.

Ellis, A. J., and Mahon, W. A. J., 1964. Natural hydrothermal systems and experimental hot waters/rock interaction (Part II). Geochim. Cosmochim. Acta, 28:1323-1357.

1967. Natural hydrothermal systems and hot water/rock interaction (Part II). Geochim. Cosmochim. Acta, 31:519-538.

Fischer, J. F., 1977. Smectite distribution, Leg 37 basalts. In Aumento, F., Melson, W. G., et al., Init. Repts. DSDP, 37: Washington (U.S. Govt. Printing Office), 833-837.

Kotov, N. V., Kurnosov, V. B., and Kholodkevich, I. V., 1978. Modeling of natural processes of volcanic rock transformation in pure and model sea water at higher P-T parameters. Lithol. Mineral. Res., 4:78-89.

Mering, J., 1975. Smectites. Soil Components. Inorgan. Compon., 2: 97-119.

Mottl, M. J., and Holland, H. D., 1978. Chemical exchange during hydrothermal lateration of basalt by seawater. I. Experimental results for major and minor components of seawater. Geochim. Cosmochim. Acta, 42:1103-1115.

Muehlenbachs, K., 1976. Oxygen isotope geochemistry of DSDP Leg 34 basalts. In Yeats, R. S., Hart, S. R., et al., Init. Repts. DSDP, 34: Washington (U.S. Govt. Printing Office), 337-339.

Naboko, S. I., 1969. The conditions of formation and peculiarities of recent hydrothermal metamorphic formation of Kuril-Kamchatka volcanic arc. Young Hydrothermally Altered Rocks and Minerals of Kamchatka and Kuril Islands: Moscow (Nauka), pp. 3-8. 
Robinson, P. T., Flower, M. F. J., Schminke, H. U., et al., 1977. Low temperature alteration of oceanic basalts, DSDP Leg 37. In Aumento, F., Melson, W. G., et al., Init. Repts. DSDP, 37: Washington (U.S. Govt. Printing Office), 775-794.

Scarfe, C. M., and Smith, D. G. W., 1977a. Secondary minerals in some basaltic rocks from DSDP Leg 37. Can. J. Earth Sci. 14:903-910.

1977b. Mineralogy and chemistry of secondary phases in some basaltic rocks from DSDP Leg 37. In Aumento, F., Melson, W. G., et al., Init. Repts. DSDP, 37: Washington (U.S. Govt. Printing Office), 795-810.
Senderov, E. E., and Khitarov, N. I., 1970. Zeolites, Their Synthesis and Conditions of Formation in Nature: Moscow (Nauka).

Seyfried, W. E., Shanks, W. C., and Bischoff, J. L., 1976. Alteration and vein formation in Site 321 basalts. In Yeats, R. S., Hart, S. R., et al. Init. Repts. DSDP, 34: Washington (U.S. Govt. Printing Office), 385-392.

Seyfried, W. E., Shanks, W. C., and Dibble, W. E., 1978. Clay mineral formation in DSDP Leg 34 basalt. Earth Planet. Sci. Lett., $41: 265-276$. 

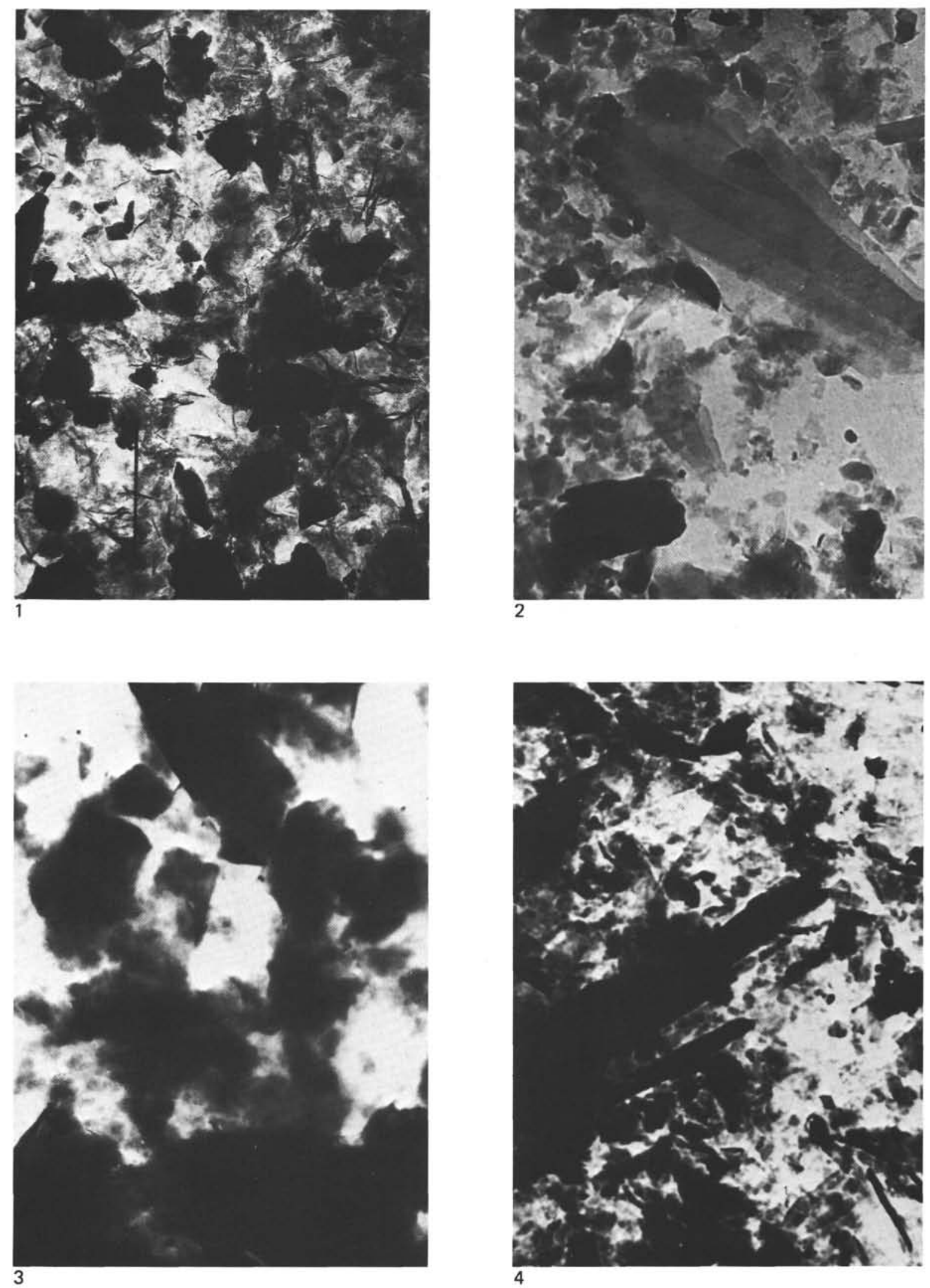

Plate 1. Electron micrographs of saponites from Leg 61 basalt.

Figure 1. Saponite from basalt groundmass, $\times 3000$; Sample $462 \mathrm{~A}-$ $55-2,50-52 \mathrm{~cm},<2 \mu \mathrm{m}$.

Figure 2-4. Saponite from veins. 2. Sample $462 \mathrm{~A}-60-3,3-5 \mathrm{~cm}$, $\times 40,000$. 3. Sample $462 \mathrm{~A}-54-2,62-64 \mathrm{~cm}, \times 30,000$. 4. Sample $462 \mathrm{~A}-61-6,2-4 \mathrm{~cm}, \times 34,000$. 

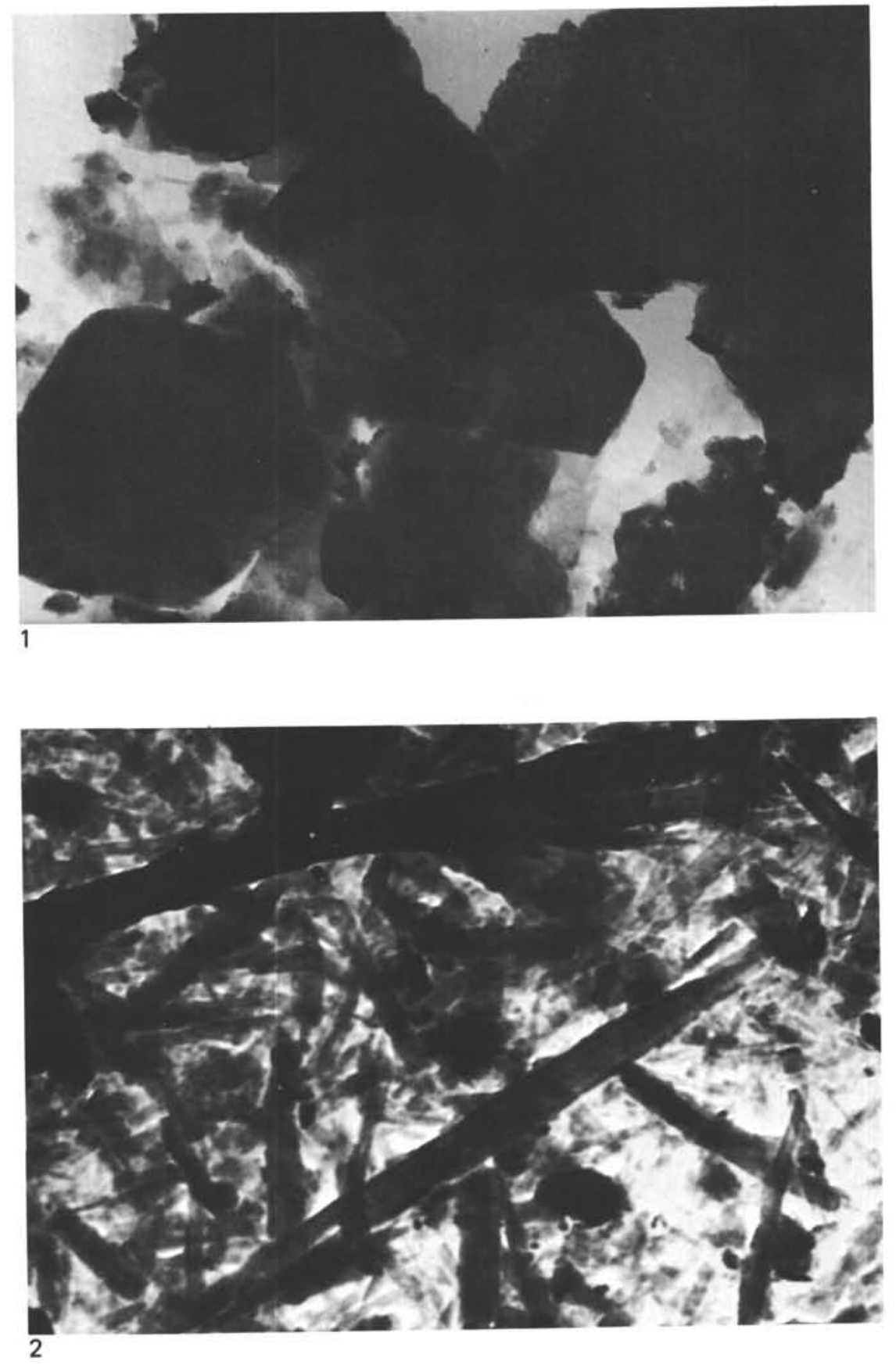

Plate 2. Electron micrographs of vein clay minerals from Leg 61 basalt.
Figure 1. Saponite with talc, $\times 30,000$; Sample $462 \mathrm{~A}-67-3,40 \mathrm{~cm}$ Figure 2. Celadonite-glauconite, $\times 40,000$; Sample 462-60-1, 86-89 $\mathrm{cm}$. 

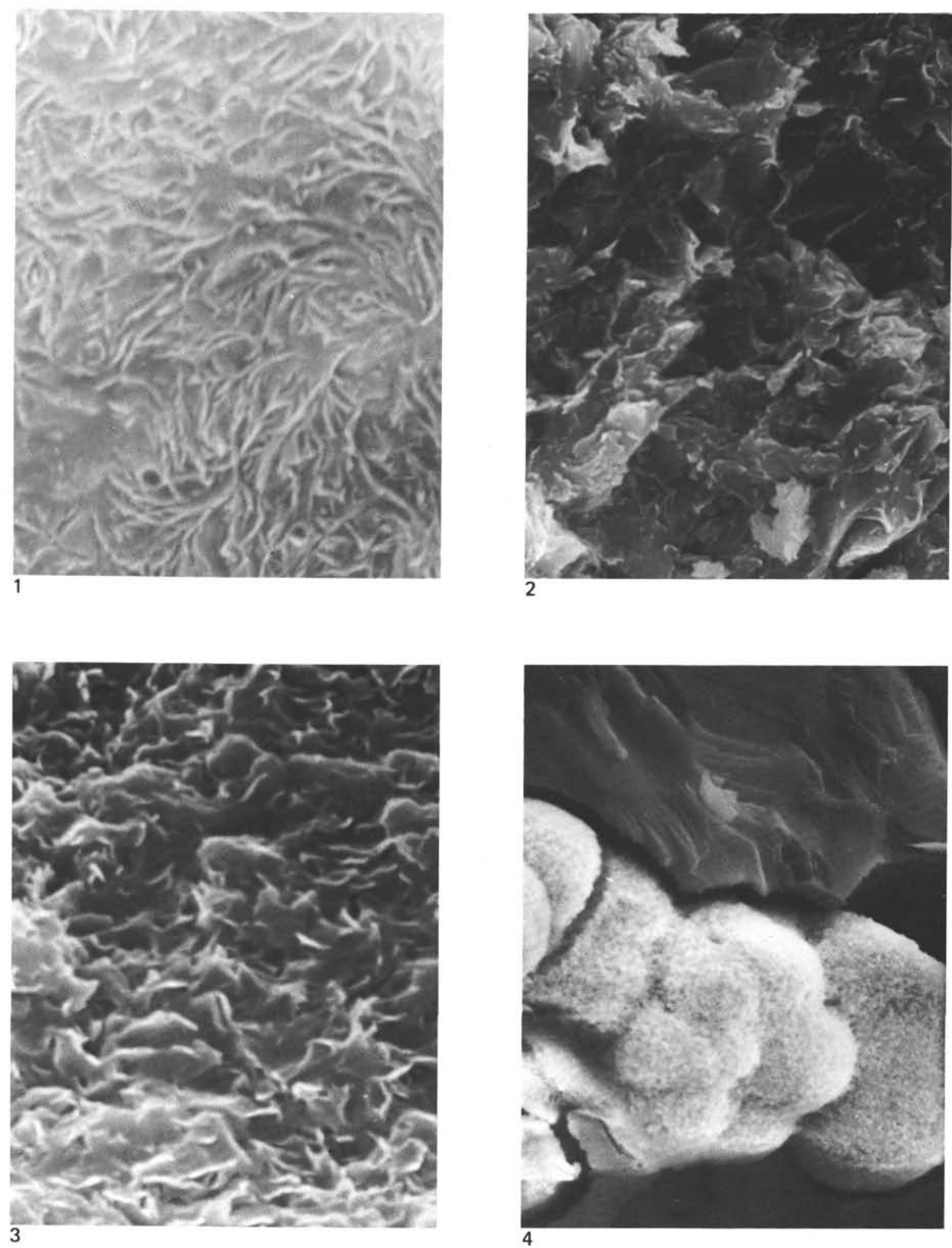

Plate 3. Electron micrographs of clay minerals from Leg 61 basalt.

Figure 1. Saponite from basalt groundmass, $\times 9000$; Sample $462 \mathrm{~A}$ $55-2,50-52 \mathrm{~cm}$.

Figure 2. Saponite with talc from vein, $\times 2000$; Sample $462 \mathrm{~A}-67-3,40$ $\mathrm{cm}$.

Figure 3. Saponite from vein, $\times 10,000$; Sample 462A-61-6, 2-4 cm. Figure 4. Chlorophaeite in basalt, $\times 600$; Sample $462 \mathrm{~A}-70-1,20-22$ $\mathrm{cm}$. 

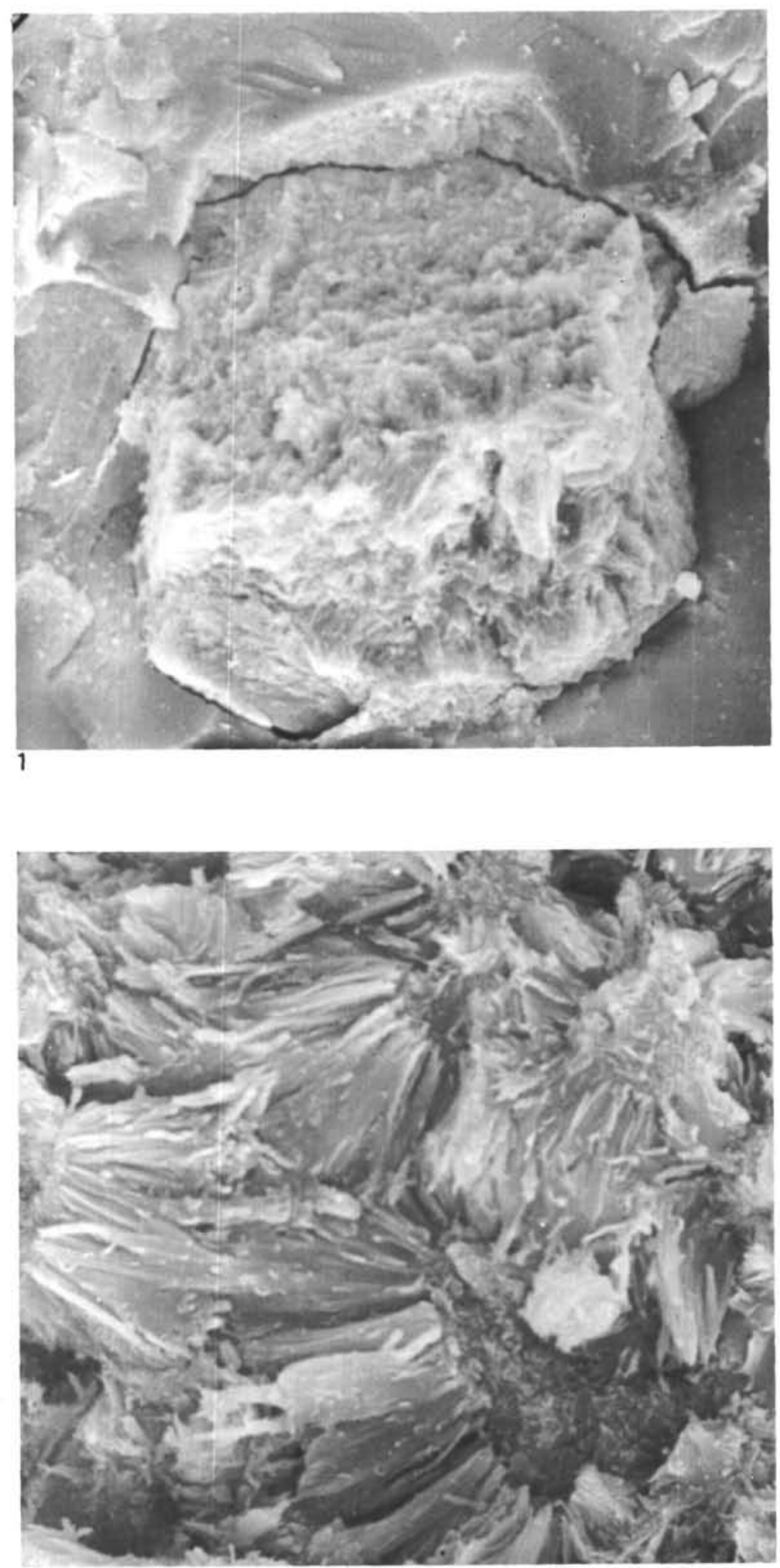

2

Plate 4. Electron micrographs of secondary minerals from Leg 61 basalts.
Figure 1 . Secondary altered olivine, $\times 600$; Sample 462 A-47-1, 95-96 $\mathrm{cm}$.

Figure 2. Celadonite-glauconite from vein, $\times 2000$; Sample 462-60-1, $86-90 \mathrm{~cm}$. 

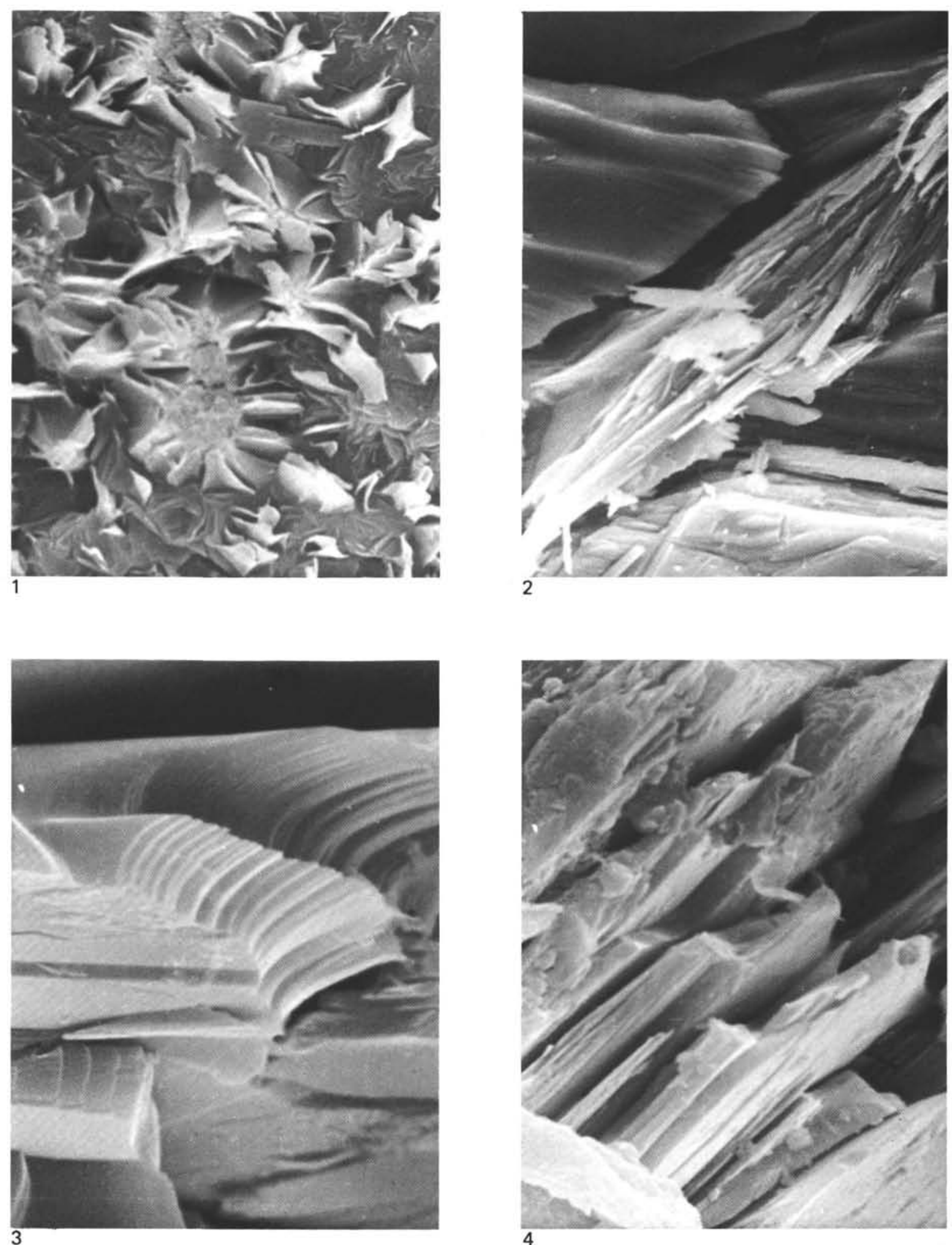

Plate 5. Electron micrographs of secondary minerals from Leg 61 basalt.

Figure 1. Saponite from vein, $\times 2000$; Sample $462 \mathrm{~A}-54-2,62-64 \mathrm{~cm}$.

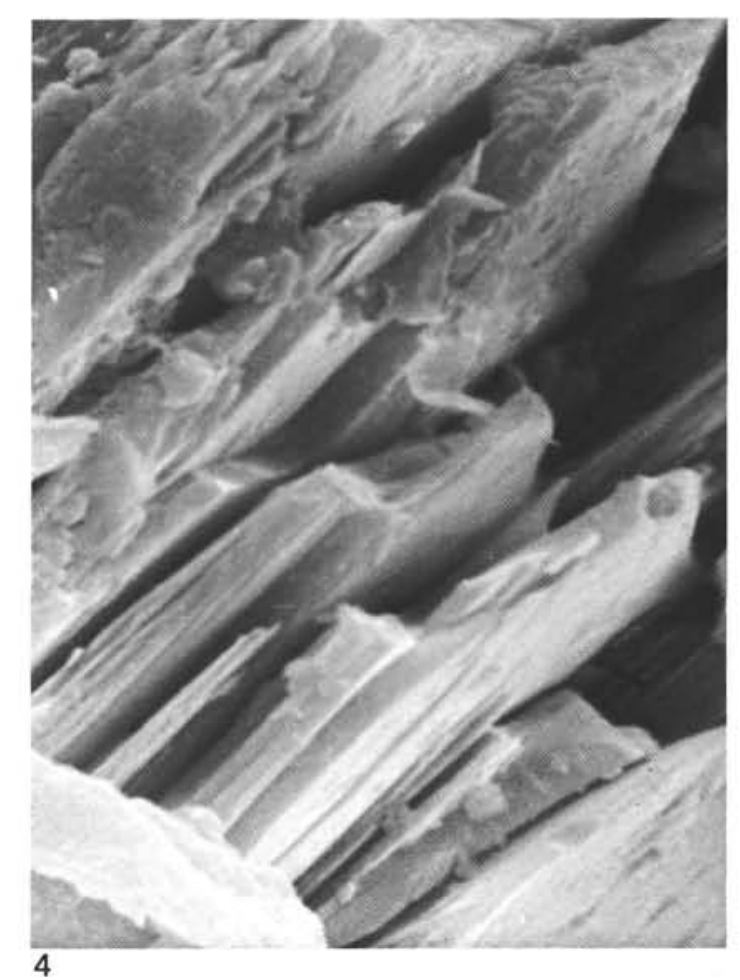

Figure 2. Chip-like saponite (below) at contact with heulandite (above), $\times 900$; Sample 462A-62-3, 48-49 cm.

Figure 3. Heulandite from vein, $\times 3000$; Sample 462A-54-2, 62-64 $\mathrm{cm}$.

Figure 4. Okenite from vein, $\times 3000$; Sample $462 \mathrm{~A}-61-6,2-4 \mathrm{~cm}$. 

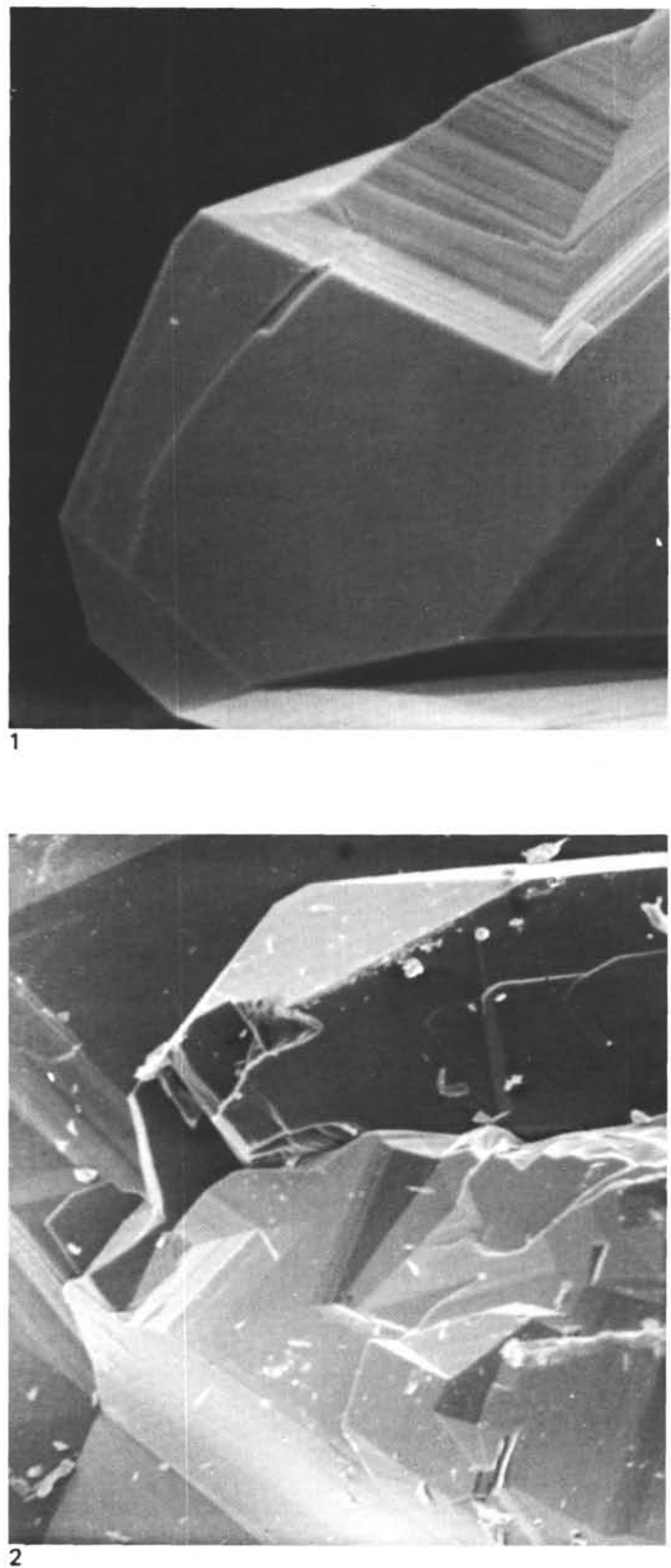

Plate 6. Electron micrographs of heulandite from veins in Leg 61 basalt.
Figure 1. Sample 462A-64-3, 46-49 cm, $\times 3000$. Figure 2. Sample $462 \mathrm{~A}-64-3,46-49 \mathrm{~cm}, \times 100$. 

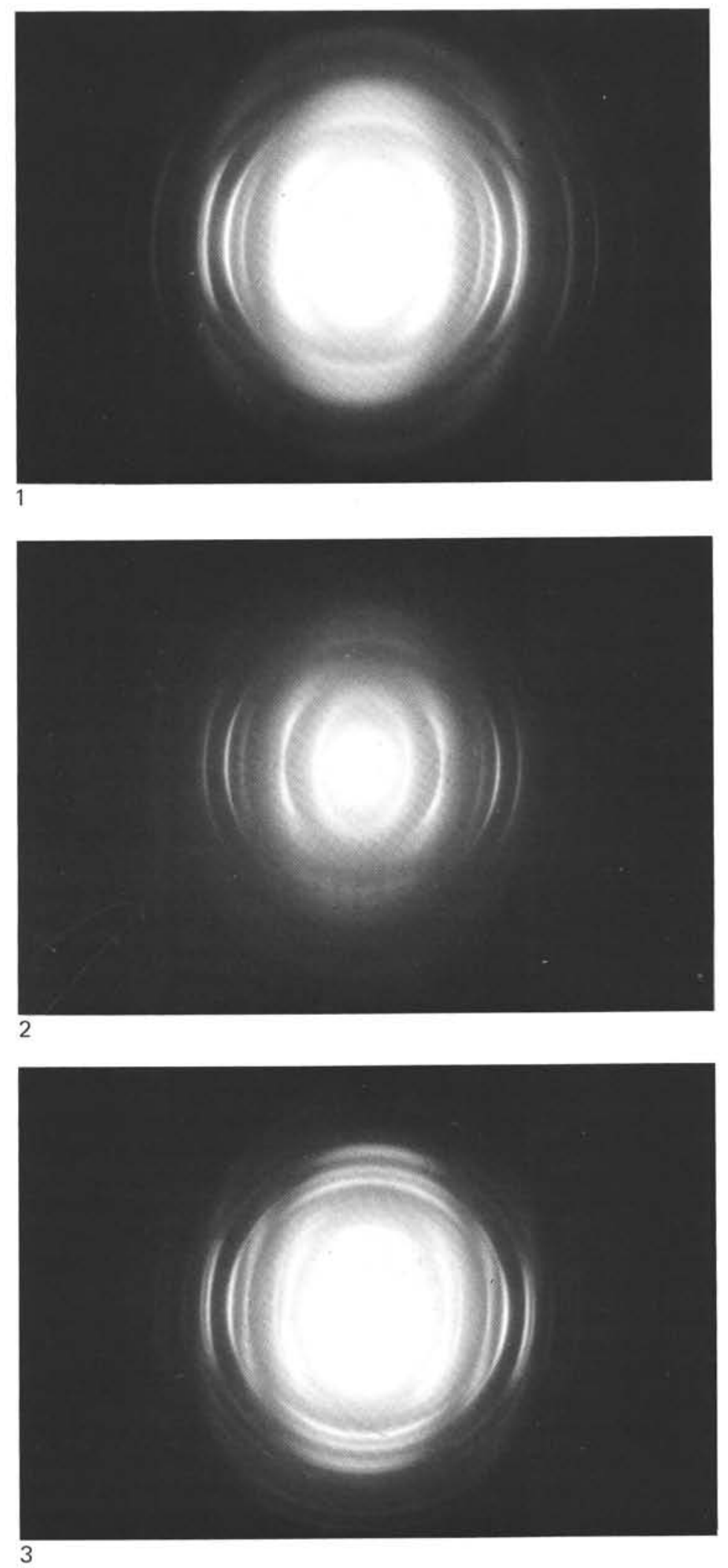

Plate 7. Electron-diffraction images of secondary minerals from Leg 61 basalt.

Figure 1. Saponite from vein; Sample 462-54-2, 62-64 cm.
Figure 2. Saponite with talc from vein; Sample 462-67-3, $40 \mathrm{~cm}$.

Figure 3. Celadonite-glauconite from vein; Sample 462-60-1, 86-89 $\mathrm{cm}$. 

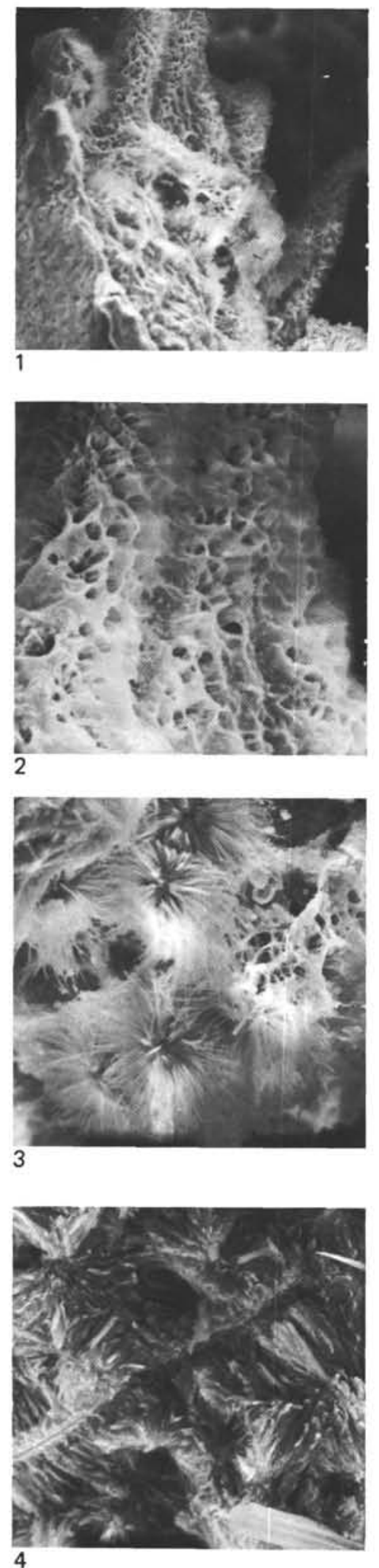

Plate 8. Electron micrographs of celadonite-glauconite from a vesicle in Leg 61 basalt (Sample 462A-14-2, 4-7 cm).

Figure 1. General view of celadonite-glauconite of different texture, $\times 80$.

Figure 2. Cactus-shaped celadonite-glauconite, $\times 300$.

Figure 3. Celadonite-glauconite of rosette texture, $\times 300$.
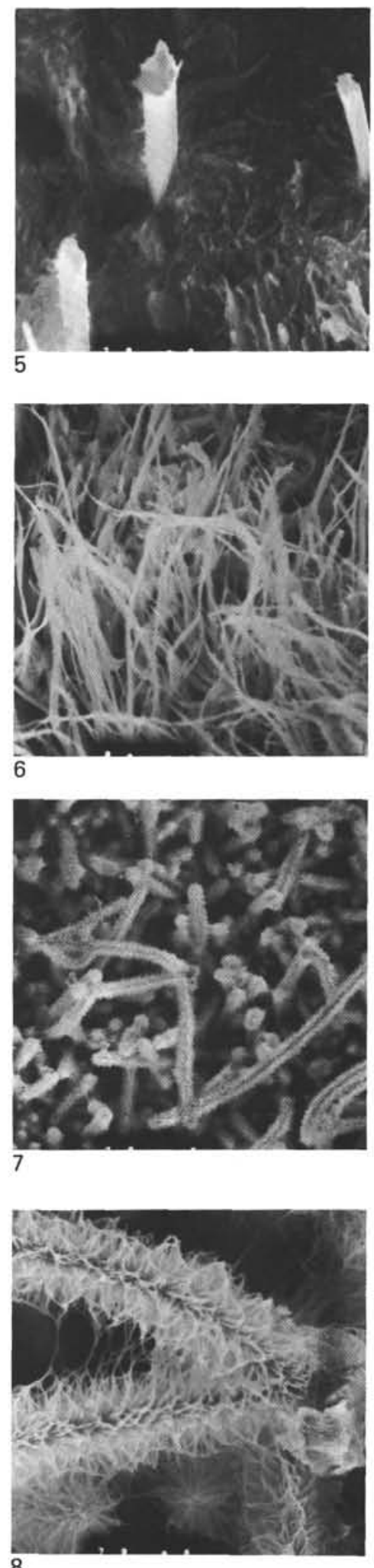

8

Figure 4. Palm-leaf-shaped celadonite-glauconite, $\times 1000$; in the lower right corner one can see a tube penetrating celadonite-glauconite of this texture.

Figure 5. Tubes as above, $\times 1500$.

Figure 6. Hair-like celadonite-glauconite, $\times 1500$.

Figure 7. Lacy plates of celadonite-glauconite covering the walls of a vesicle, $\times 50$.

Figure 8 . The same plates, $\times 300$. 